(II) Nordiska ministerrådet

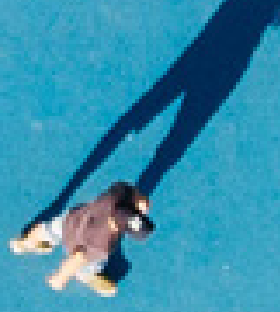




\section{Den segregerade staden}

En nordisk översikt

Moa Tunström och Shinan Wang

Nord 2019:006

ISBN 978-92-893-6001-2 (PRINT)

ISBN 978-92-893-6002-9 (PDF)

ISBN 978-92-893-6003-6 (EPUB)

http://dx.doi.org/10.6027/Nord2019-006

(c) Nordiska ministerrådet 2019

Layout: Agnete Schepelern och Frederik Storm

Foto: Jonas Jacobsson / Unsplash

\section{Det nordiska samarbetet}

Det nordiska samarbetet är ett av världens mest omfattande regionala samarbeten. Det omfattar Danmark, Finland, Island, Norge och Sverige samt Färöarna, Grönland och Åland.

Det nordiska samarbetet är politiskt, ekonomiskt och kulturellt förankrat och en viktig del av europeiskt och internationellt samarbete. Den nordiska gemenskapen arbetar för ett starkt Norden i ett starkt Europa.

Det nordiska samarbetet vill stärka nordiska och regionala intressen och värderingar i en global omvärld. Gemensamma värderingar länderna emellan bidrar till att stärka Nordens ställning som en av världens mest innovativa och konkurrenskraftiga regioner.

\section{Nordiska ministerrådet}

Nordens Hus

Ved Stranden 18

DK-1061 Köpenhamn

www.norden.org 


\section{Den segregerade staden}

\section{Innehåll}

5 Förord

6 Segregationen utmanar den nordiska självbilden

8 De många indikatorerna

16 Vilka är egentligen segregerade?

18 Bostadspolitikens betydelse

27 Bostäder för flyktingar och asylsökande

28 Grannskapseffekter och den byggda miljöns utformning

30 Diskriminering och stigmatisering

32 Hela staden är segregerad

34 Kartor och figurer

36 Referenser 


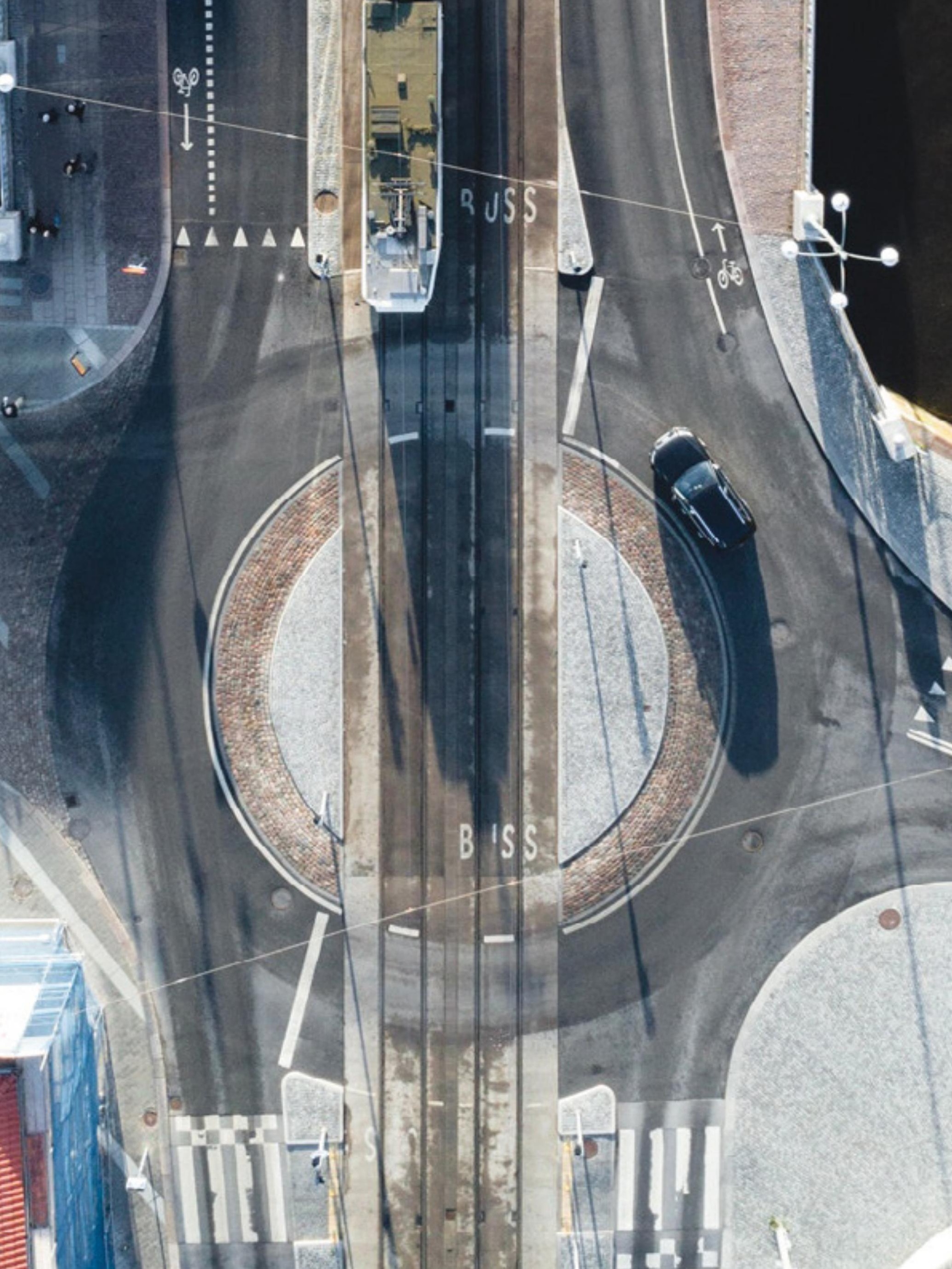




\section{Förord}

De nordiska länderna är lika varandra på många sätt. De är perifera och glesbefolkade välfärdsstater som domineras av små och medelstora städer. Det finns också likheter när det gäller den urbana segregationen och det är en fråga som kommit att bli omdebatterad och ofta relaterad till välfärd, socioekonomiska orättvisor och invandring.

Även om det är möjligt att tala om en nordisk välfärdsmodell så finns det skillnader i exempelvis bostadspolitik och efterkrigstidens stadsutveckling som illustrerar vikten av den nationella och lokala politiken och som gör det nordiska sammanhanget särskilt intressant. Den segregerade staden utmanar den nordiska självbilden och de nordiska idealen.

Den här rapporten ingår i ett tema om segregation inom projektet Nordisk samverkan om integration. Projektet syftar till att underlätta samarbete mellan de nordiska länderna när det gäller integration av flyktingar och immigranter, och är ett initiativ från Nordiska ministerrådet. Nordens välfärdscenter samarbetar med Nordregio i projektet och riktar ett stort tack till författaren Moa Tunström.

Eva Franzén Direktör, Nordens välfärdscenter

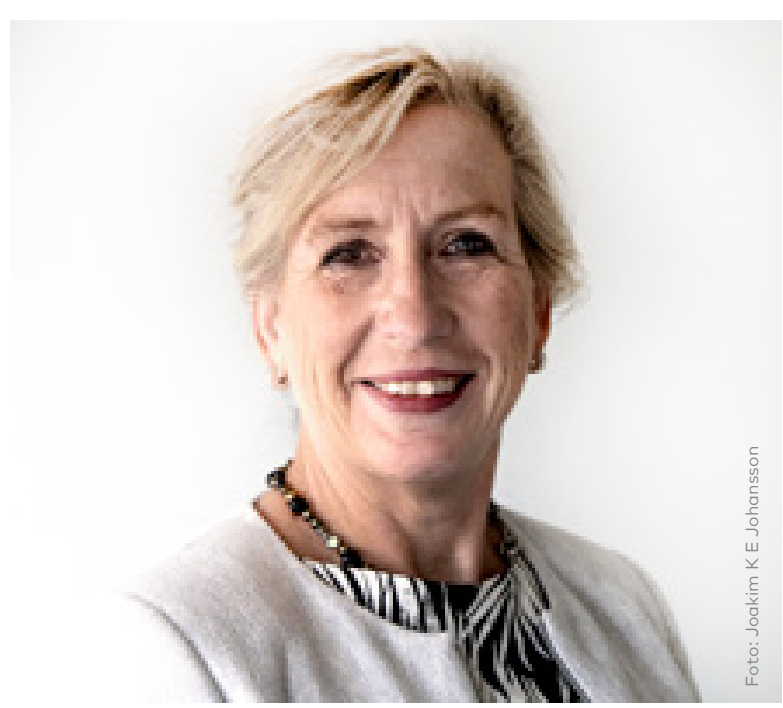

Notera att den här publikationen till stor del är baserad på en tidigare publicerad rapport från Nordregio, Segregated cities and planning for social sustainability - a Nordic perspective (Nordregio Working paper 2016:3). Delar av rapporten har här förkortats, redigerats och översatts till svenska. I tillägg har nya kartor gjorts av Shinan Wang, Nordregio.

Den ursprungliga rapporten skrevs av Moa Tunström, Timothy Anderson och Liisa Perjo på Nordregio, och kan laddas ner från www.nordregio.org 


\section{Segregationen utmanar den nordiska självbilden}

Segregation i städer handlar ofta om att olika sociala grupper är separerade med avseende på var de bor. Problem som rör segregation och integration utgör viktiga ansvarsområden och utmaningar för städer, och en segregerad stadsmiljö kan ses som ett symtom på sociala orättvisor i vidare bemärkelse. Demografiska förändringar i europeiska städer medför nya kunskaper, arbetstillfällen, möjligheter och livsstilar, men de ställer även planerare och offentliga aktörer inför utmaningar som rör diskriminering och bristande jämlikhet. Människor migrerar som flyktingar från konfliktområden och för en möjlighet till arbete och ett bättre liv eller från landsbygden till stadsområden inom sitt eget land.

I denna kortfattade översikt av aktuell forskning om boendesegregation ligger fokus på strukturella orsaker till segregationen. Det innebär att det snarare är planeringspolitik och tendenser i den socioekonomiska utvecklingen som diskuteras, istället för specifika åtgärder och projekt för social integration. Det finns dock en självklar arena där dessa två synsätt på segregation möts, och det är i lokalsamhället och dess rum och platser för social samvaro. Det är viktigt att komma ihåg att den integrerade staden är ett resultat av såväl strategier och initiativ på mikronivå, i grannskap och mellan individer, som av initiativ och utveckling på makronivå. Det är också viktigt att strategier som anses lycko- samma i en stad eller stadsdel inte alltid går att exakt kopiera. Städer och stadsdelar är olika och styrs olika, och det har betydelse för vilken typ av integrationspolitik som behövs och kan anses lyckosam.

De nordiska länderna påminner om varandra $\mathrm{i}$ många avseenden. De är perifera, glesbefolkade välfärdsstater med små och medelstora städer, och segregationen sker enligt liknande mönster. Resultatet av ett urval studier tyder på att segregationen ökar i Norden och att detta allmänt ses som ett hinder för tillhandahållandet av effektiva offentliga tjänster, ekonomisk tillväxt och social hållbarhet.

Andersson et al (2010) konstaterar i en översikt av etnisk bostadssegregation i de nordiska länderna (förutom Island) att den etniska bostadssegregationen är framträdande i alla större svenska städer. Deras slutsats är att Sverige som land är positivt gentemot immigranter men att det finns en pågående debatt om en mer restriktiv politik och de rapporterar om svårigheter för nya immigranter att, till exempel, hitta bostäder och anställning. Några år senare måste detta uttalande ses mot bakgrund av både den globala politiska utvecklingen och hur den offentliga debatten om immigration i Europa och Sverige har utvecklats sedan 2010, från en debatt om en restriktiv politik till en restriktiv praxis. 
Städer och stadsdelar är olika och styrs olika, och det har betydelse för vilken typ av integrationspolitik som behövs och kan anses lyckosam
Med avseende på Danmark uppmärksammar samma översikt den ökade uppdelning på bostadsmarknaden under de senaste 30 åren, där det finns en korrelation mellan inkomstnivåer och upplåtelseformer (Andersson et al 2010). Avseende Norge drar Andersson et al (2010) slutsatsen att det finns en tydlig etnisk skiljelinje i de ekonomiska och sociala integrationsmönstren. Finland, slutligen, är lite annorlunda, eftersom det är först under de senaste åren som immigrationen har ökat. Denna ökning har dock sammanfallit med den ekonomiska recessionen, vilket har lett till ökande skillnader, äldre befolkning och ökad etnisk mångfald (Andersson et al 2010).

Segregationen i nordiska städer utmanar de ideal om jämlikhet och rättvisa som ofta förknippas med regionen och ställer nordiska stadsplanerare inför den komplicerade uppgiften att navigera mellan olika behov och önskemål hos en allt mer blandad och dynamisk befolkning. 


\section{De många indikatorerna}

Eftersom segregation oundvikligen är ett mångbottnat och svårdefinierat fenomen kan det vara svårt att fastställa vilka skalor och variabler som är viktiga när man närmar sig ämnet. Till exempel kan en kartläggning av andel av utlandsfödda på regional nivå ge resultat som skiljer sig stort från en kartläggning på kommun- eller stadsdelsnivå. Zoomar man ut för mycket kan det vara svårt att se även de allra tydligaste mönstren av välstånd och fattigdom, medan ett smalt fokus på en stadsdel kan göra att man missar vidare mönster i staden eller regionen. Försök att definiera vad som utgör en minoritetsgrupp eller hur man bör mäta relativ fattigdom kan resultera i debatt. Kartorna i den här skriften illustrerar våra segregerade nordiska storstäder med hjälp av indikatorerna inkomst och andel befolkning med utländsk bakgrund, på stadsdelsnivå. Båda dessa indikatorer är vanliga när segregation i städer diskuteras.

I Andersens (2010) undersökning av segregationen i Köpenhamn mäter han fenomenet genom en analys av fördelningen av bostäder och grannskapstyper över inkomstgrupper. Denna typ av analys av bostäder kontra inkomster är den vanligaste. En rad studier om segregation i Norden tar istället upp rörligheten på arbetsmarknaden (Aldén och Hammarstedt 2014;
Vaattovaara och Kortteinen 2012; Wessel 2013) och immigrationen (Dhalmann 2013; Jørgensen 2015; Kauppinen 2002; Lödén 2008) som nyckelfaktorer med konsekvenser för boendesegregation. Ett exempel är Wessel (2013), som gör en kritisk analys av den skeva arbetsmarknaden i Oslo och drar slutsatsen att män snarare än kvinnor, och västerländska immigranter snarare än icke-västerländska immigranter tenderar att hamna i höginkomstsektorn, tendenser som ligger i linje med stadens ökande inkomstklyftor och segregation.

Segregationen i skolor är dessutom ett växande problem och en generell utveckling mot ökad möjlighet att välja skola har ökat denna effekt (se t ex Rangvid 2007 och Trumberg 2011). I Köpenhamn bedömer Rangvid (2007) att den etniska skolsegregationen för vissa elevgrupper kan jämföras med den amerikanska utvecklingen. I Sveriges fall konstaterar Bunar (2010) liksom Szulkin och Jonsson (2007) att den etniska segregationen i storstadsskolor har ökat, och de menar att det finns ett behov av åtgärder som ökar den etniska och sociala blandningen i klassrummen. I kontrast till detta drar Poikolainen (2012) slutsatsen att skolsegregation utgör ett mindre problem i Finland, där det fortsättningsvis finns en stor tilltro till lokala grundskolor. Resultatet av senare forskningsprojekt pekar dock på ökande skolsegregation även i Finland (Bernelius 2013; Seppänen 2015). 
1. Förändring av befolkningsandel med utländsk bakgrund* i Stockholm mellan 2003 och 2016, i procent
$<2,5$
$2,5-5$
$5-7,5$
$7,5-10$
$>10$

Rinkeby-Kista

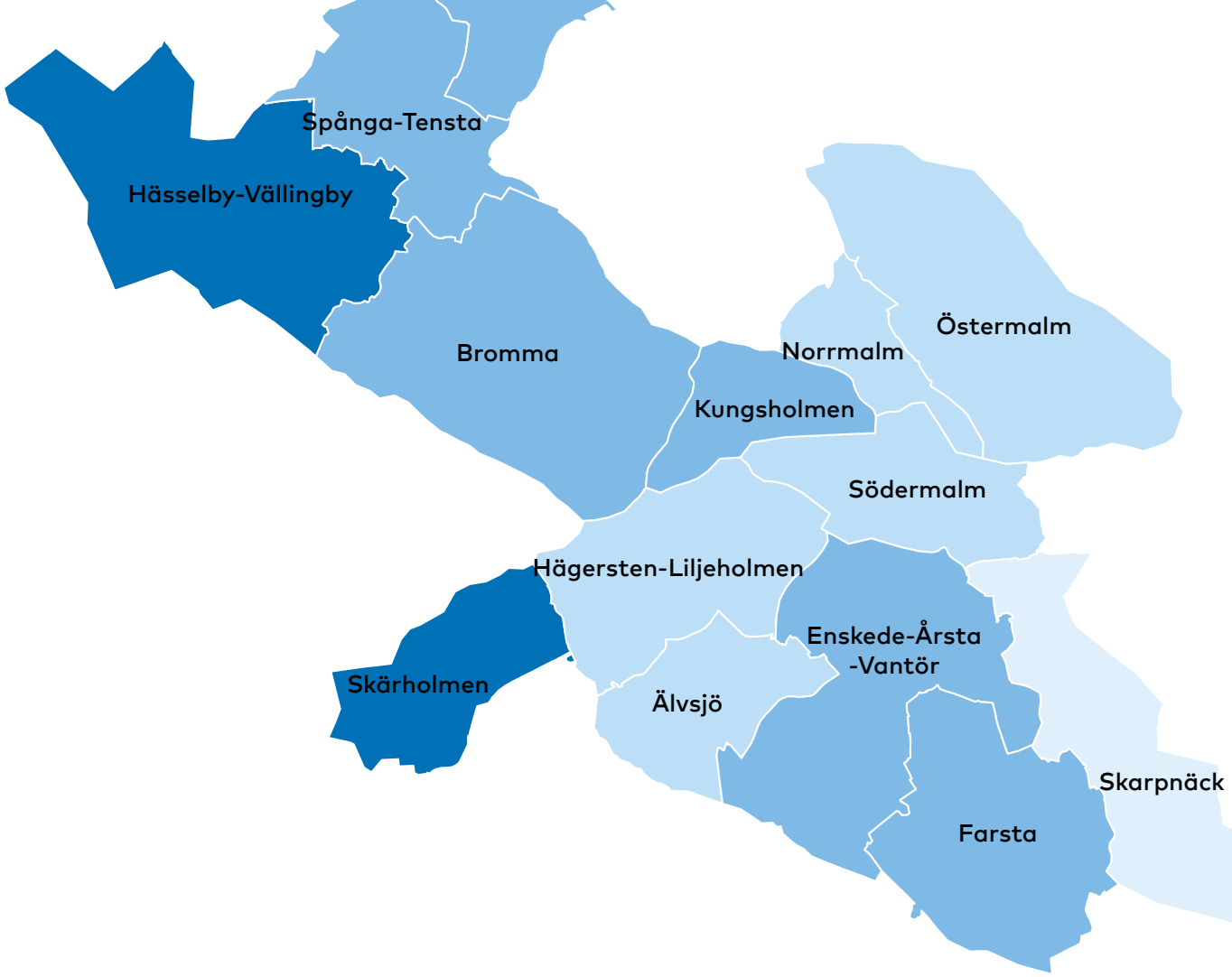

\subsection{Befolkningsandel med utländsk bakgrund, 2006-2016}

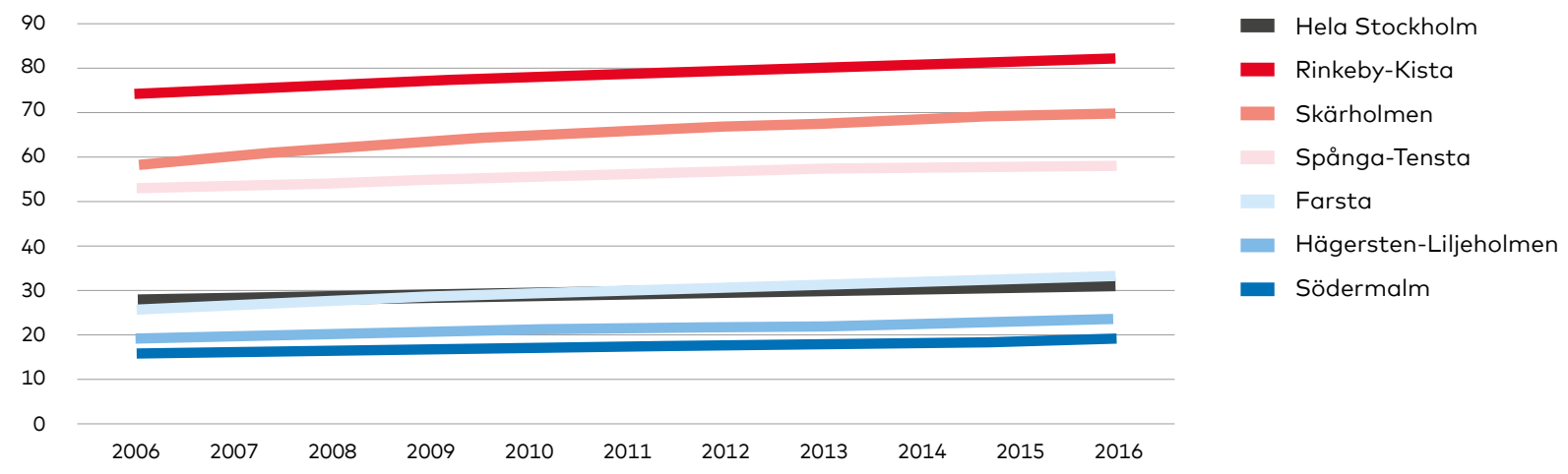

*Med utländsk bakgrund avses immigranter och individer som är födda i Sverige, men vars föräldrar är immigranter. Genomsnitt i Stockholm: 5,1. Källa: Stockholms stad, Öppna data. NRO2306a @ Nordregio \& NLS Finland för administrativa gränser. Beskrivning av kartan och figuren, se sidan 34 
2. Förändring av befolkningsandel med utländsk bakgrund* i Köpenhamn mellan 2000 och 2017, i procent
$<2,5$
$2,5-5$
$5-7,5$
$7,5-10$
$>10$

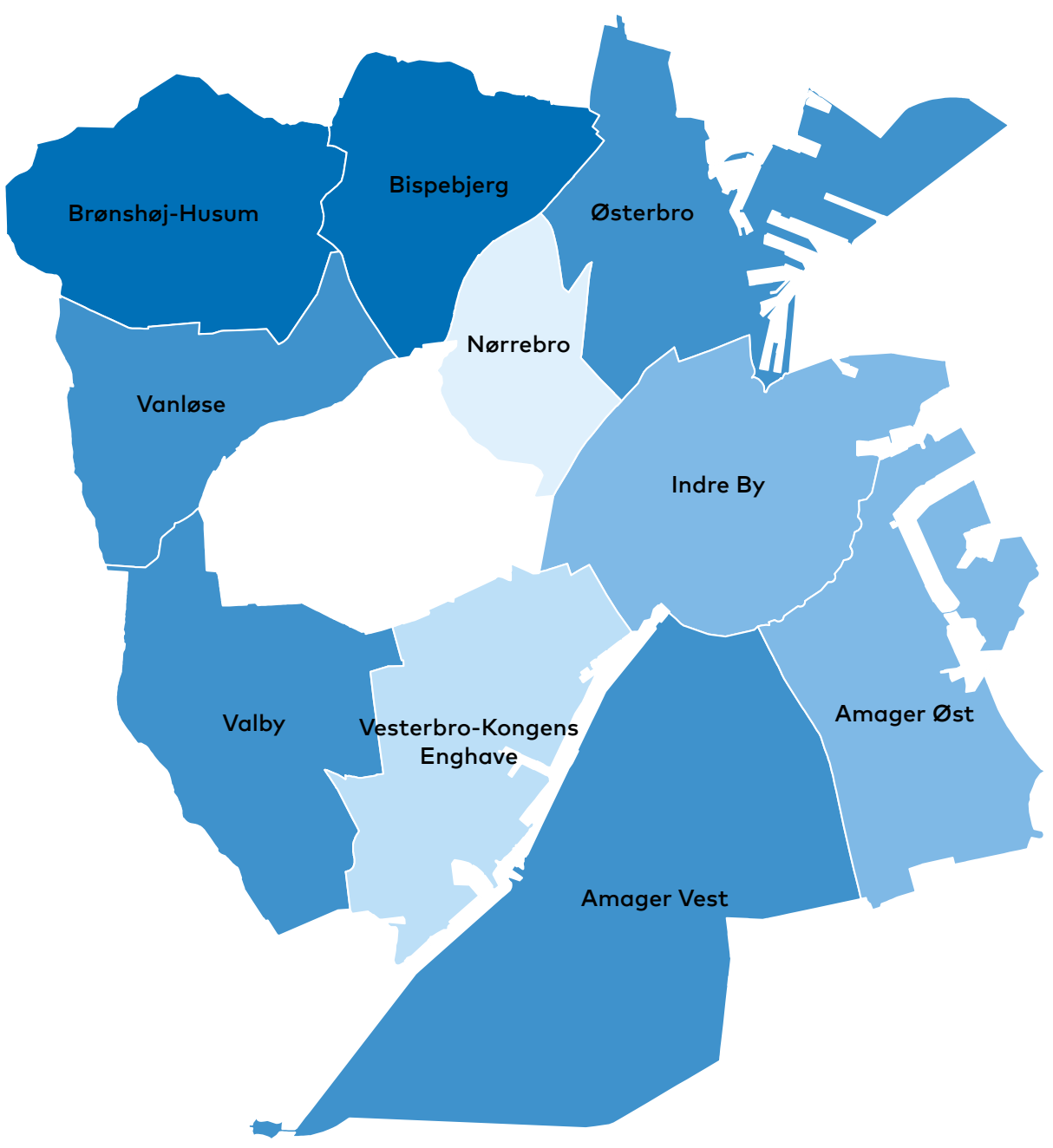

\subsection{Befolkningsandel med utländsk bakgrund, 2000-2017}

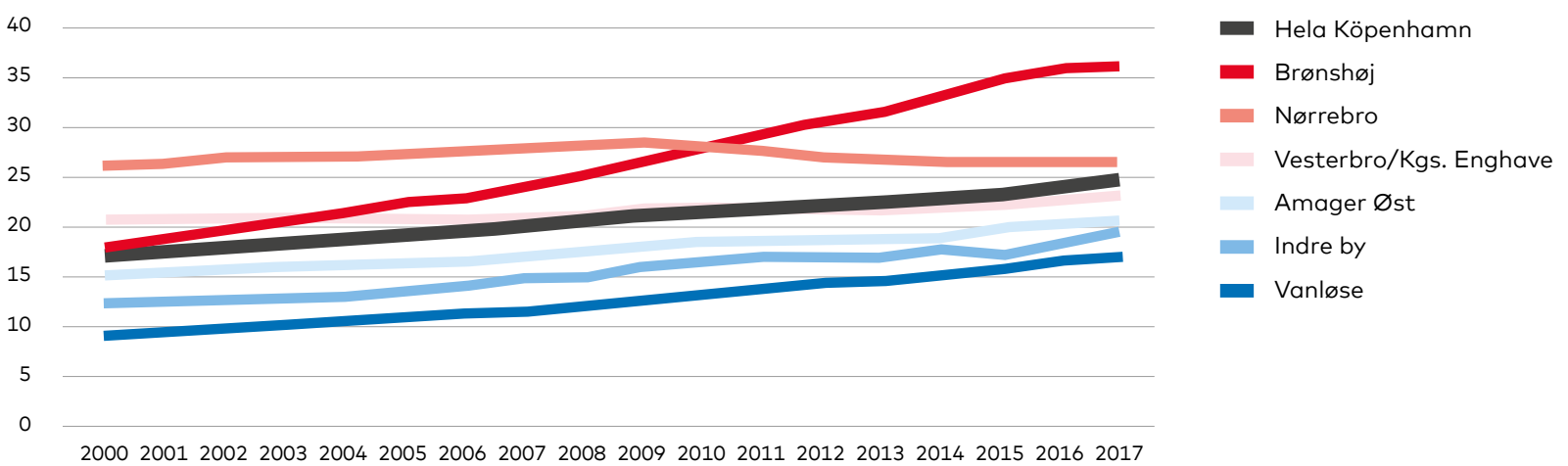

*Med utländsk bakgrund avses immigranter och individer som är födda i Danmark, men vars föräldrar är immigranter. Genomsnitt i Köpenhamn: 7,3. Källa: Köpenhamns kommun; Öppna data Köpenhamn. NR02306b @ Nordregio \& NLS Finland för administrativa gränser.

Beskrivning av kartan och figuren, se sidan 34 
3. Förändring av befolkningsandel med utländsk bakgrund* i Oslo mellan 2000 och 2016, i procent
$<2,5$
$2,5-5$
$5-7,5$
$7,5-10$
$>10$

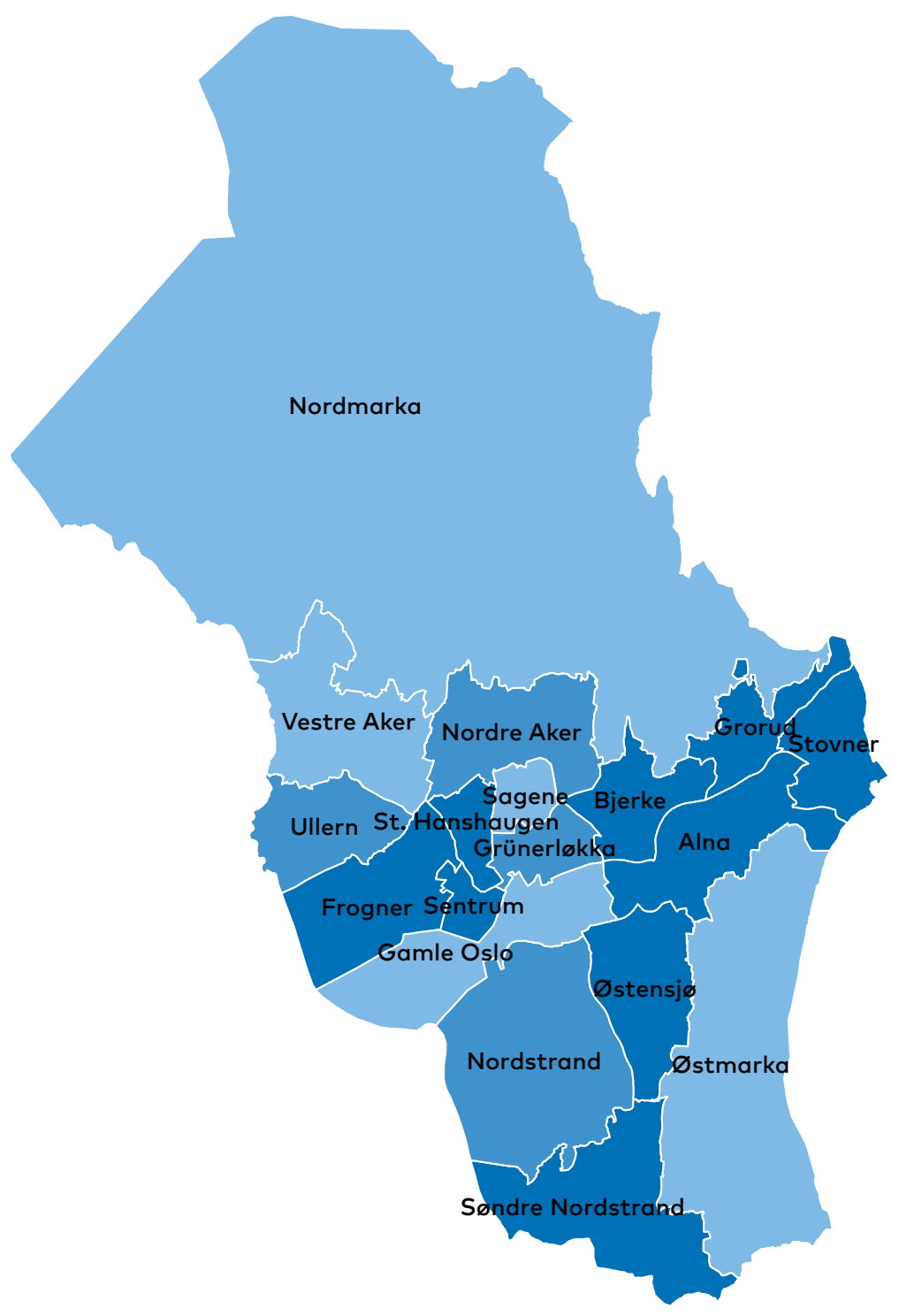

\subsection{Befolkningsandel med utländsk bakgrund, 2000-2016}

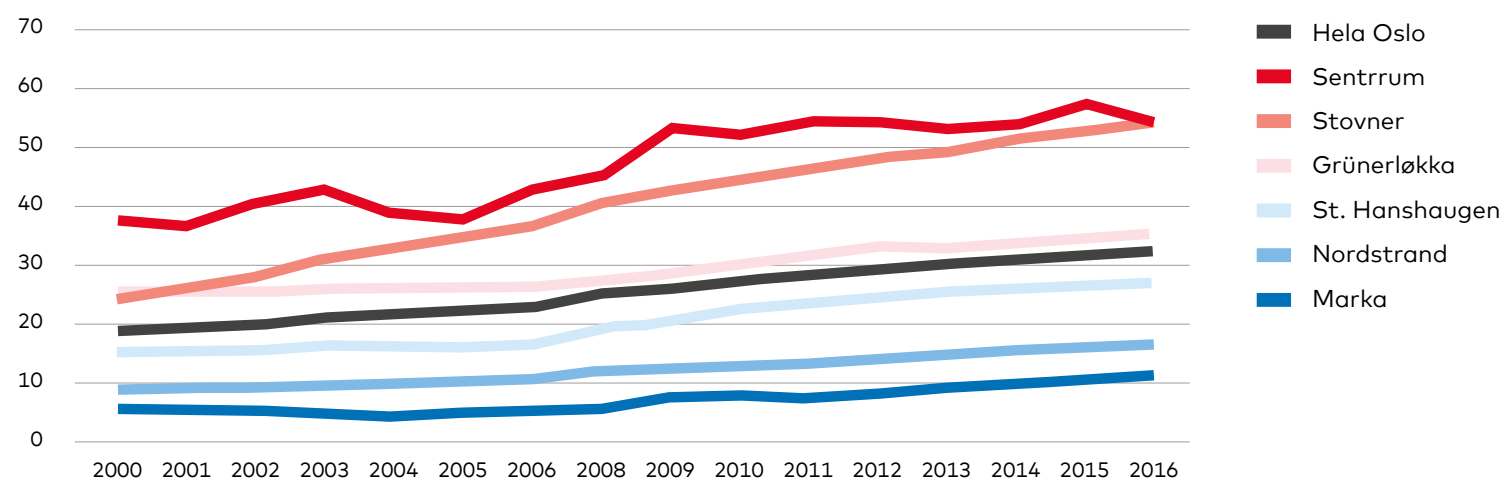

*Med utländsk bakgrund avses immigranter och individer som är födda i Norge, men vars föräldrar är immigranter. Genomsnitt i Oslo: 5,1. 
4. Förändring av befolkningsandel med utländsk bakgrund* i Helsingfors mellan 2011 och 2017, i procent

$<0$

$0-2,5$

$2,5-5$

$5-7,5$

$7,5-10$

$>10$

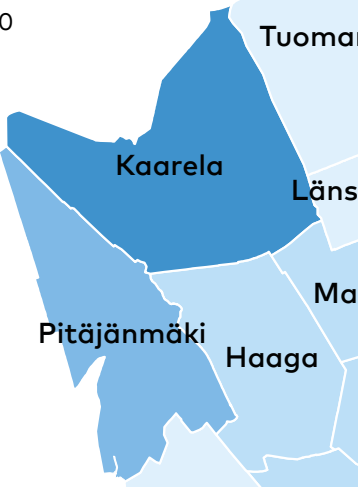

\section{a}

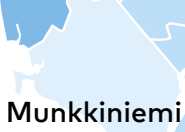

Pasila

Vanhakaupunki

Itä-Pakila

Pukinmäki

Malmi

Oulunkylä

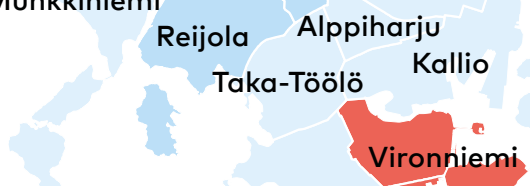

Kulosaari

Kampinmalmi

Latokartano

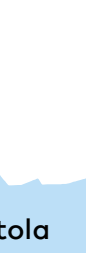

Lauttasaari

Ullanlinna

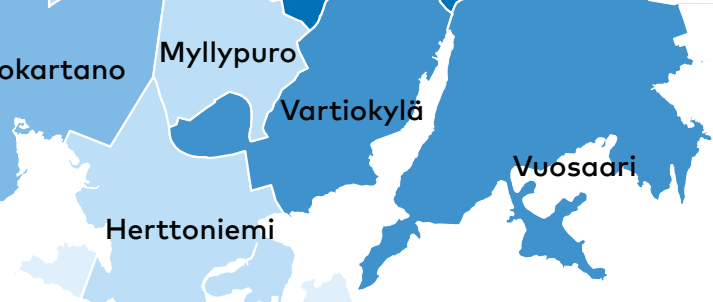

Vallila

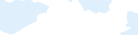

\section{Laajasalo}

Luttasaari

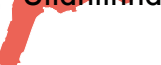

\subsection{Befolkningsandel med utländsk bakgrund, 2011-2017}

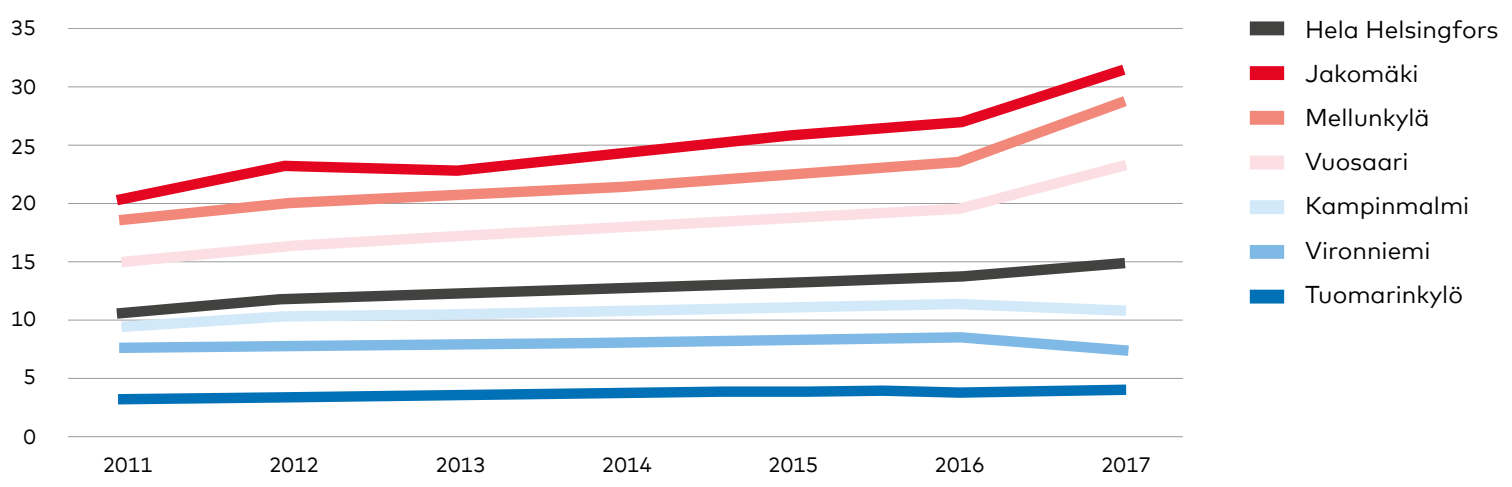

*Med utländsk bakgrund avses immigranter och individer som är födda i Finland, men vars föräldrar är immigranter. Genomsnitt i Helsingfors: 4,2. Källa: Helsingfors per region; Helsingfors stads kartservice. NR02306d @ Nordregio \& NLS Finland för administrativa gränser. Beskrivning av kartan och figuren, se sidan 34 
Forskningen fokuserar ofta på koncentrationer av immigranter och etniska minoriteter som indikatorer på segregation. Utvecklingen är tydligast i Sverige, där den etniska bostadssegregationen i Stockholm, Göteborg och Malmö är kraftigare än i många andra europeiska städer (Östh et al 2015). Ekonomisk ojämlikhet ökar också i takt med segregationen i de nordiska länderna (ESPON 2014). I Danmark kan vi se en stor segregation mellan etniska och socioekonomiska grupper, särskilt i Köpenhamn (Andersen 2010). Flera forskare har observerat att denna uppdelning är mest märkbar när man jämför personer som bor i hyresrätter (och särskilt subventionerade sociala bostäder) med personer som bor i bostadsrätter (Andersen 2010; Christensen 2015; Jørgensen 2015). Utöver den rumsliga isoleringen från vita danskar har immigranter med en bakgrund utanför EU och Nordamerika en avsevärt högre arbetslöshet och relativ fattigdom (Jørgensen 2015).

I Norge antyder forskning att både etnisk och socioekonomisk bostadssegregation utgör ett allt större problem (Andersson et al 2010; Søholt et al 2012; Turner \& Wessel 2013; Wessel 2015). Den norska forskningen har oftast fokuserat på Oslo eftersom den staden har genomgått en kraftigare demografisk förändring och ökade klyftor jämfört med andra städer i landet. Turner och Wessel (2013) observerar en etnisk uppdelning, då många invånare med ickeeuropeisk bakgrund (främst somalier, irakier och marockaner) förblir koncentrerade i hyresrätter och/eller i allmänt fattiga delar av staden. I en senare bedömning av Oslo konstaterar Wessel (2015) att både inkomstklyftorna och den etniska segregationen har ökat väsentligt sedan 2005.

I Finland har bostadssegregationen inte fått samma uppmärksamhet som i Sverige eller Danmark, och segregationsforskningen fokuserar främst på Helsingfors. Forskarna är allmänt överens om att segregationen i Helsingfors inte är lika kraftig som i många andra större städer i Nordeuropa, men man observerar dock att den socioekonomiska och etniska segregationen har ökat sedan den ekonomiska krisen drabbade Finland på 1990-talet (Vaattovaara \& Kortteinen 2012; Vilkama et al 2014).

Med avseende på etnicitet började segregationen i Helsingforsområdet att öka under 2000-talet, när både antalet immigranter i Finland generellt sett, och de etniska skillnaderna mellan områden, ökade (Vilkama 2011). Vilkama et al (2014) har jämfört förändringar i genomsnittsinkomster, den infödda befolkningens utbildningsnivå, sysselsättningsnivån och andelen invånare med utländska modersmål i Helsingforsområdet mellan 2002 och 2012. De konstaterar att den genomsnittliga inkomst- och utbildningsnivån allmänt har ökat i både den infödda befolkningen och befolkningen med utländska modersmål i praktiskt taget alla grannskap i storstadsregionen. Resultatet visar dock skillnader i förändringstakt (Vilkama et al 2014). Som ett exempel beskriver de hur genomsnittsinkomsten och utbildningsnivån ökade mest i grannskap som redan hade genomsnittliga eller höga inkomst- och utbildningsnivåer, vilket antyder en ökad klyfta mellan rika och socioekonomiskt svaga grannskap (Vilkama et al 2014). Den sociala rörligheten verkar med andra ord minska. Fattigdomen är koncentrerad till specifika områden och låga inkomster, låga utbildningsnivåer, hög arbetslöshet och en hög andel invånare med utländska modersmål förekommer i stort i samma grannskap (Vilkama et al 2014). Kortteinen och Vaattovaara (2007) observerar att utöver det faktum att resurssvaga grupper i högre grad är koncentrerade till vissa områden, är även de mest välbeställda grupperna allt mer koncentrerade till vissa delar av Helsingforsregionen.

Island har bara en liten andel immigranter, men visar redan tecken på rumslig isolering bland immigrant- och minoritetsbefolkningen i Reykjavik. Sindradóttir och Júlíusdóttir (2008) påpekar att stadens bosättningsmönster visar tendenser till segregation och de menar att denna ska ses som en pågående process som sannolikt inte kommer att förbättras utan någon form av insats eller omfördelning på Reykjaviks bostadsmarknad. 


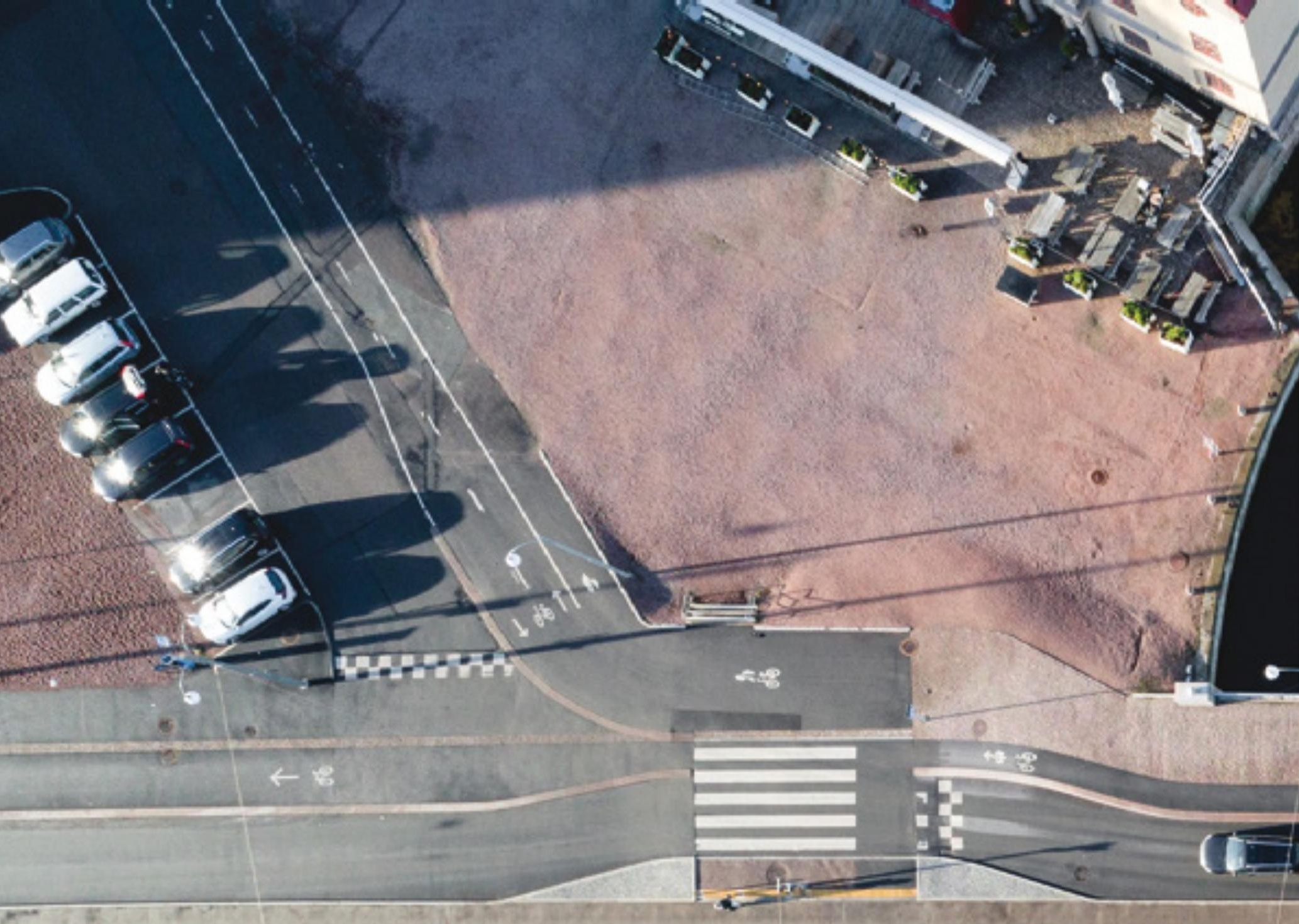

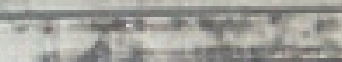

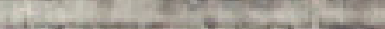

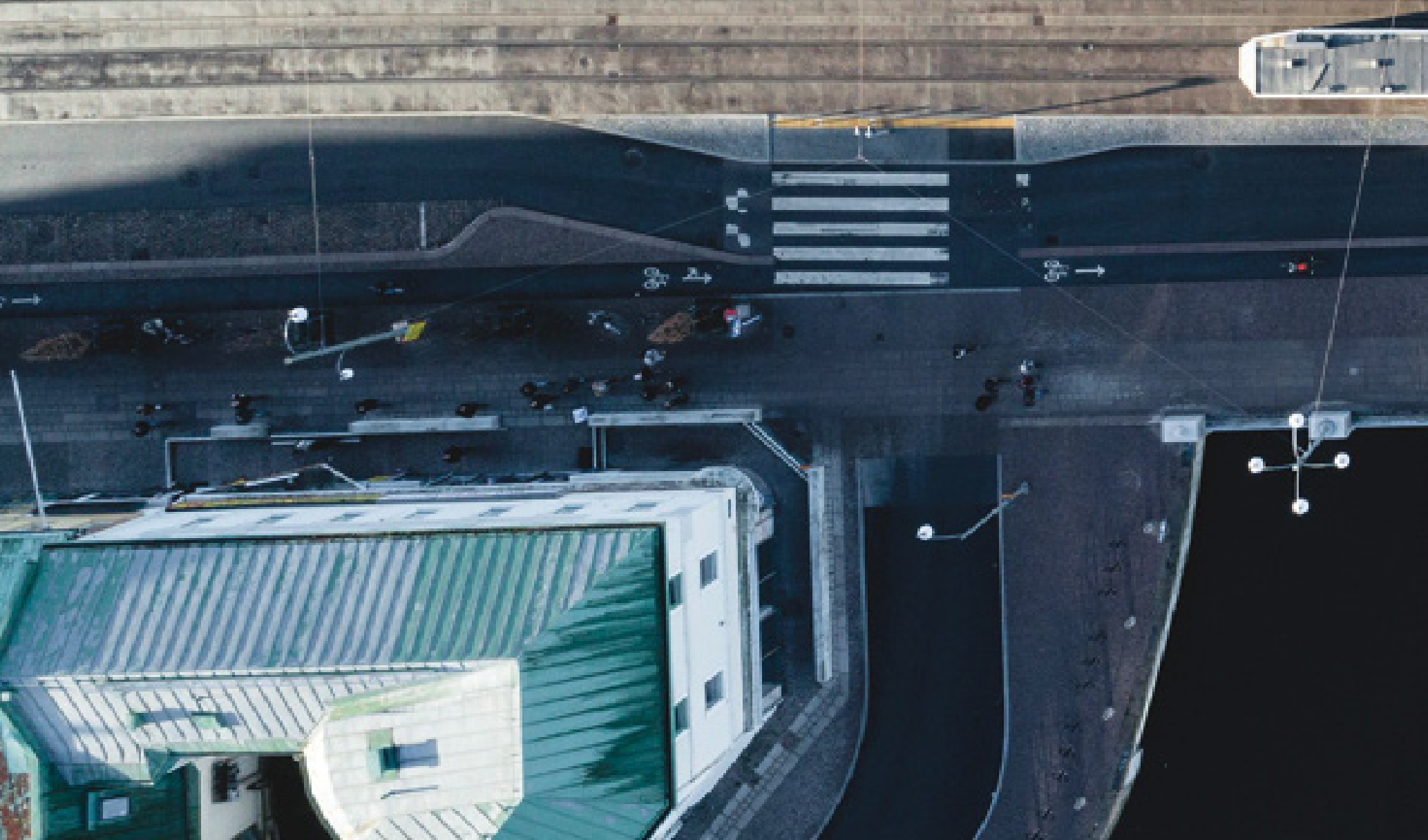




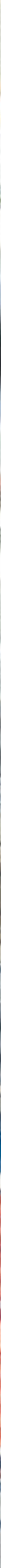




\section{Vilka är egentligen segregerade?}

Det är viktigt att notera - trots vårt fokus här på invånare med utländsk bakgrund - att forskningen i allt högre grad pekar på det faktum att det är de socioekonomiskt resursstarka som är mest segregerade i de nordiska huvudstäderna (Marcińczak et al 2015). Till exempel har Stockholms fattigare förorter en relativt hög etnisk mångfald, med både nyanlända och etablerade grupper från sydöstra Europa, Afrika, Mellanöstern, Ostasien och Sydamerika ( $̊$ slund et al 2010).

\section{De mest välbestållda och privilegierade gruppernas flyttmönster spelar störst roll för bostadsmarknaden och demografin i nordiska städer}

Den mest utmärkande egenskapen för dessa grupper är att de inte är vita svenskar och att de, delvis på grund av detta, tilldelas ett narrativ om att vara annorlunda och betraktas som en särskilt problematisk grupp. Det finns även allt mer bevis (se Andersson 2013; Östh et al 2015) på att de mest välbeställda och privilegierade gruppernas flyttmönster spelar störst roll för bostadsmarknaden och demografin i nordiska städer.
Trots detta fokuserar många artiklar om segregation på immigranters och etniska minoriteters situation, och väldigt begränsade insatser görs för att problematisera och bedöma den mer välbeställda lokalbefolkningens bidrag till segregationsmönstret. Några undantag från denna trend är Rodenstedt (2014), som kritiserar den sociorumsliga reproduktionen av överklasstadsdelar i Malmö och Andersson (2013), som har skrivit om den potentiella roll som white flight och white avoidance har i skapandet av privilegierade och homogena delar av Stockholm.

I en studie av mödrar med småbarn i Örebro i Sverige fann Lilja (2015) att diskursen om polarisering och immigration som problem påverkade deras val av var i staden de ville att barnen skulle växa upp. Trots att de uttryckte en önskan om att barnen skulle uppleva ett område med kulturell och social mångfald så undvek de att bosätta sig i sådana stadsdelar (Lilja 2015). 


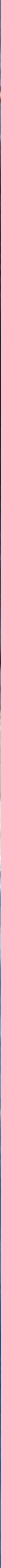




\section{Bostadspolitikens betydelse}

Trots att de nordiska länderna är välfärdsstater som liknar varandra så skiljer sig bostadspolitiken åt mellan dem. Bostadsmarknaden omfattar köp, försäljning och hyra av olika bostäder, liksom fall där köp och hyra kombineras. Bostadstillgången är av yttersta vikt för integrationen. Hur kommer man in på bostadsmarknaden som nyanländ invånare $i$ en stad i de nordiska länderna? Svaret på detta är nyckeln till segregationsmönster, och de offentliga bostadsbolagen - och andra aktörer på bostadsmarknaden - är aktörer i integrationsprocessen. De har både lokal kunskap och makt, och kan därmed i hög grad påverka utvecklingen i en stadsdel.

Finland har fler upplåtelseformer än de andra länderna, och de blandar ägarskap och hyra på olika sätt. Dessutom saknas uttryckligen "social housing" i Sverige, medan i Danmark och Norge är "social housing" och allmännyttiga bostäder delvis överlappande termer. Allmännyttan har olika ställning i respektive land, det vill säga är mer eller mindre stigmatiserad. Frågan om vem som är hyresvärd kan också vara viktig, eftersom den visar vilka de relevanta aktörerna på bostadsmarknaden är. I Norge är en betydande andel av hyresvärdarna privatpersoner, medan kommunala bostadsbolag är huvudaktörer $\mathrm{i}$ Sverige. Allmännyttan i Sverige består av kommunala bolag, medan i Danmark och Finland kan fackföreningar eller allmännyttiga organisationer fungera som hyresvärdar.
Bostadsmarknadens struktur och funktionalitet är av betydelse för var immigranter bosätter sig. Domineras bostadsmarknaden av bostadsrätter? Finns det privata hyresbostäder eller subventionerade sociala bostäder? Bosättningspolitiken har också kopplingar till kommunernas ansvar och därmed till det allmännyttans ansvar. Till exempel skulle nyanlända immigranters möjligheter att etablera sig på bostadsmarknaden i Sverige enligt Boverket vara minimal om de allmännyttiga bostadsbolagen hade stränga krav på inkomster eller fast anställning.

Vad gäller bostadspolitiken är marknadssegmentering ett stort tema i litteraturen om segregation i nordiska städer. Uppdelning av marknaden uppstår när olika upplåtelseformer görs tillgängliga och attraktiva för olika typer av hushåll (Andersson et al 2010). Medan låginkomstgrupper tenderar att bilda kluster i allmännyttiga bostäder tenderar höginkomstgrupper att bilda kluster i bostadsrätter. Denna uppdelning av upplåtelseformer leder ofta till etnisk segregation (Andersen et al 2013). Den politiska reaktionen på detta är ofta någon typ av insatser som främjar social blandning, dvs. en blandning av upplåtelseformer på bostadsmarknaden. 
5. Förändring i medelinkomst* i Stockholm, 2005-2015, i procent

$<30$

$30-40$

$40-50$

$50-60$

$>60$

\section{Rinkeby-Kista}

\section{Spånga-Tensta}

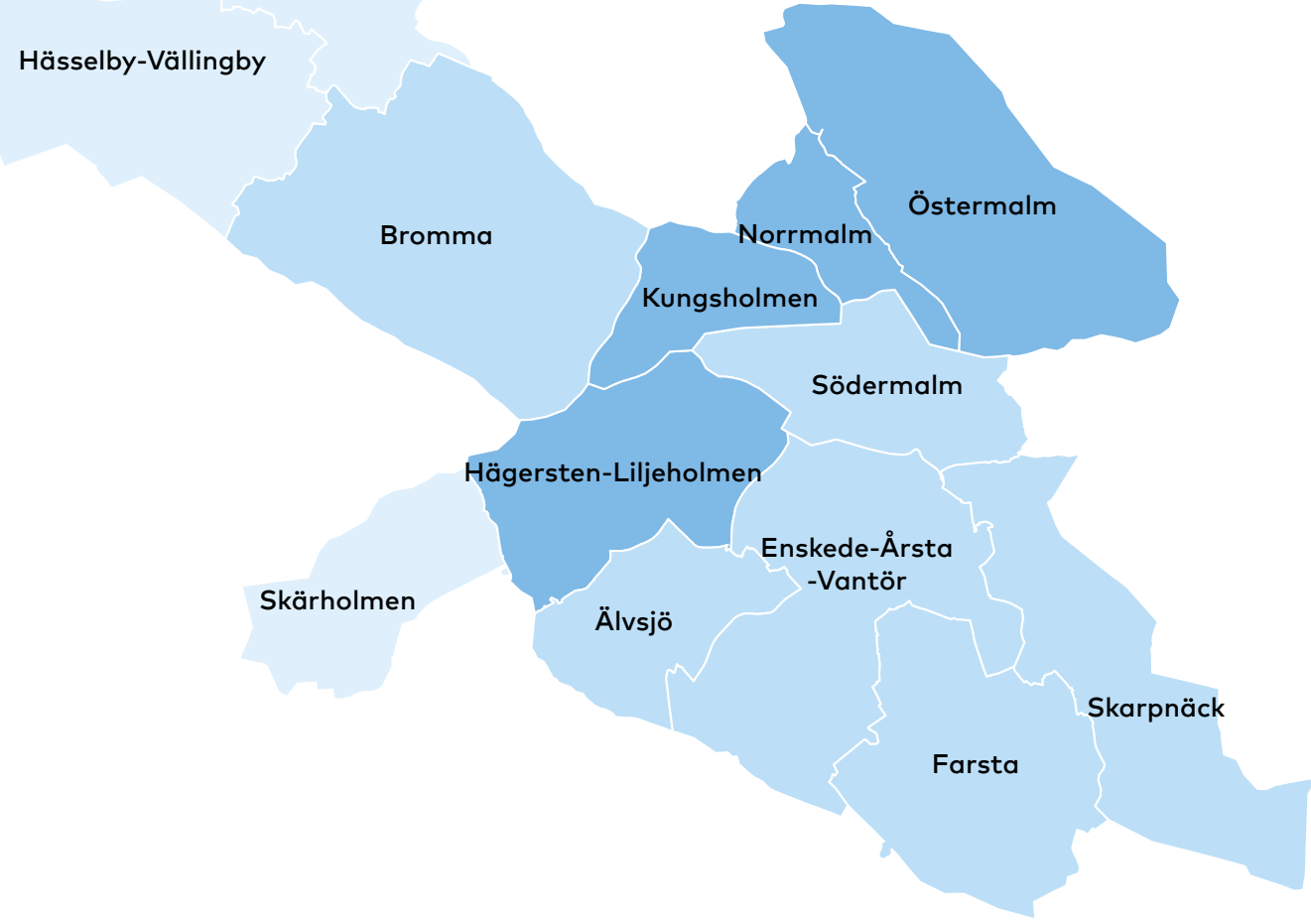

5.1. Medelinkomst i SEK för invånare som är 16 år eller äldre, 2005-2015

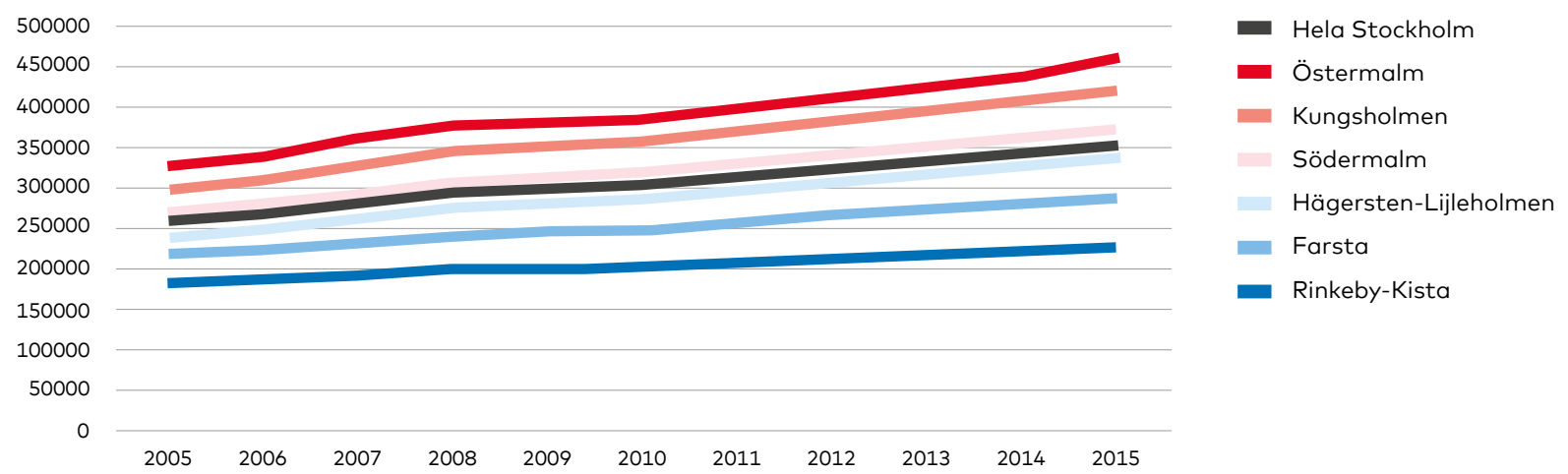

*Inkomst avser den totala inkomsten. Genomsnitt i Stockholm: 35,1. Källa: Stockholms stad, Öppna data NR0372a (C) Nordregio \& NLS Finland för administrativa gränser. Beskrivning av kartan och figuren, se sidan 35 
6. Förändring i disponibel medelinkomst i Köpenhamn, 2000-2015, i procent

$<30$

$30-40$

$40-50$

$50-60$

$>60$

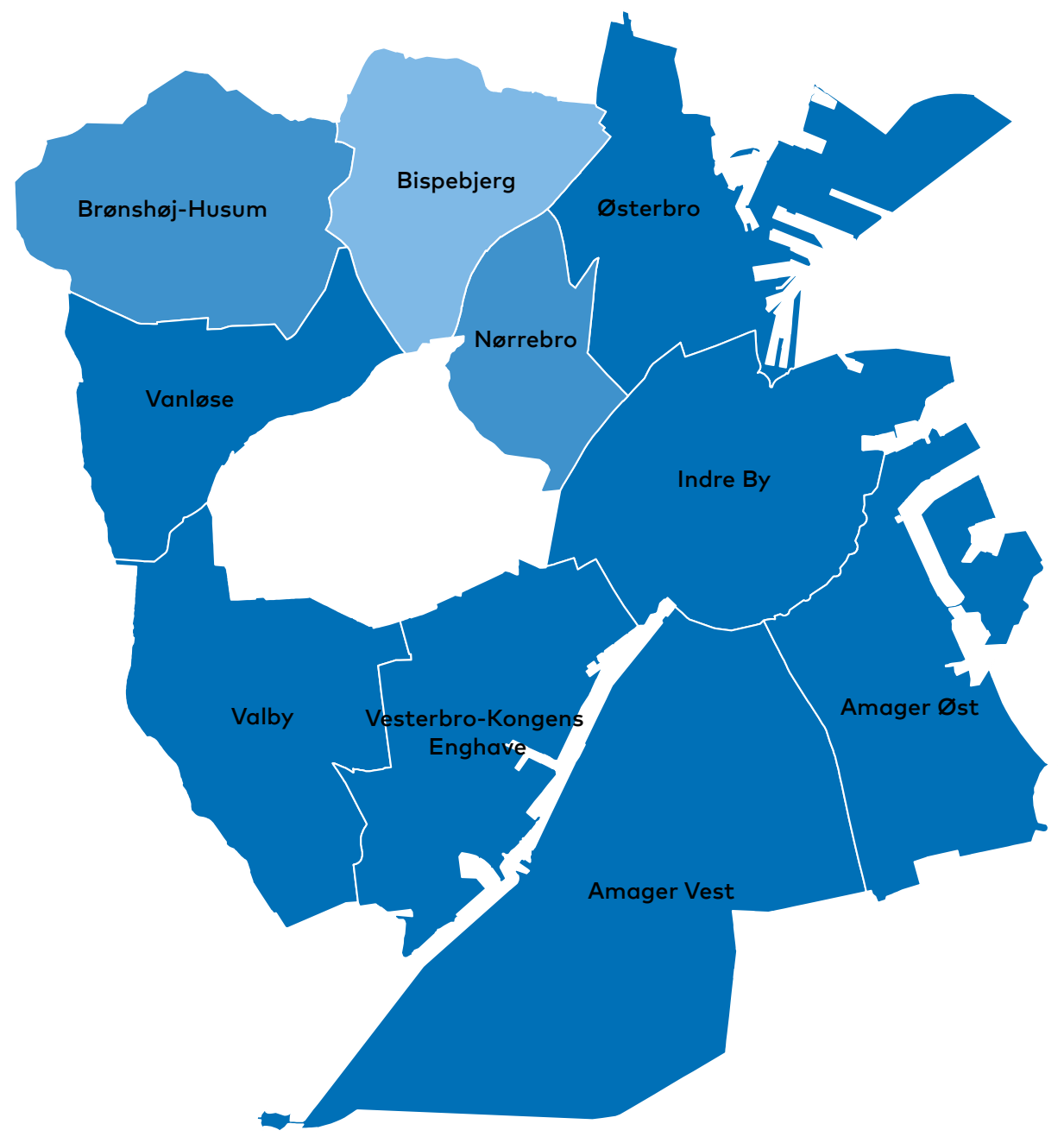

\subsection{Disponibel medelinkomst i DKK, 2000-2015}

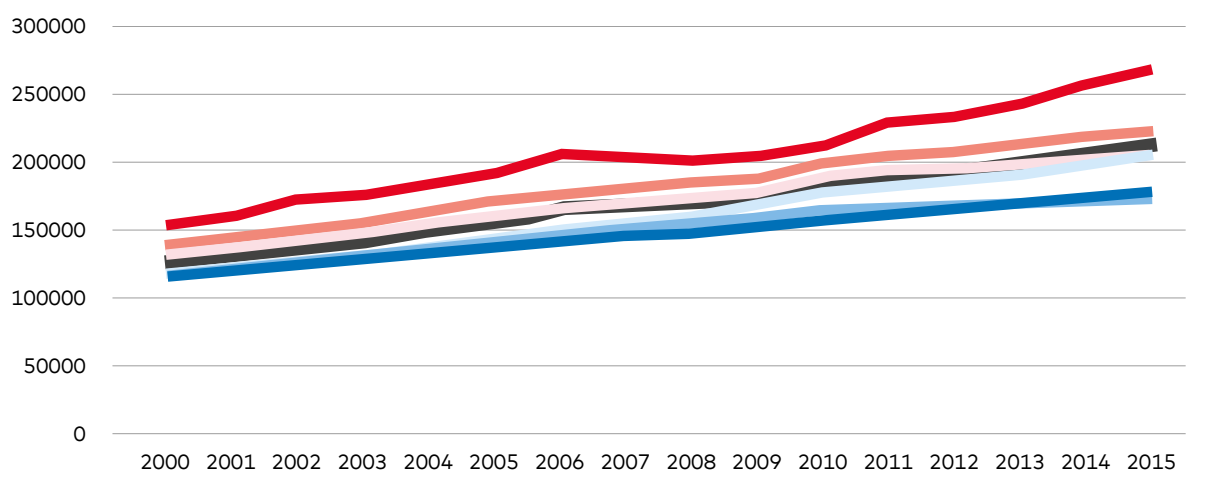

- Hela Köpenhamn

- Indre by

- Vanløse

Brønshøj

- Vesterbro/Kgs. Enghave

Bispebjerg

nørrebro 
7. Förändring i medelinkomst* i Oslo, 2000-2016, i procent
$<30$
$30-40$
$40-50$
$50-60$
$>60$

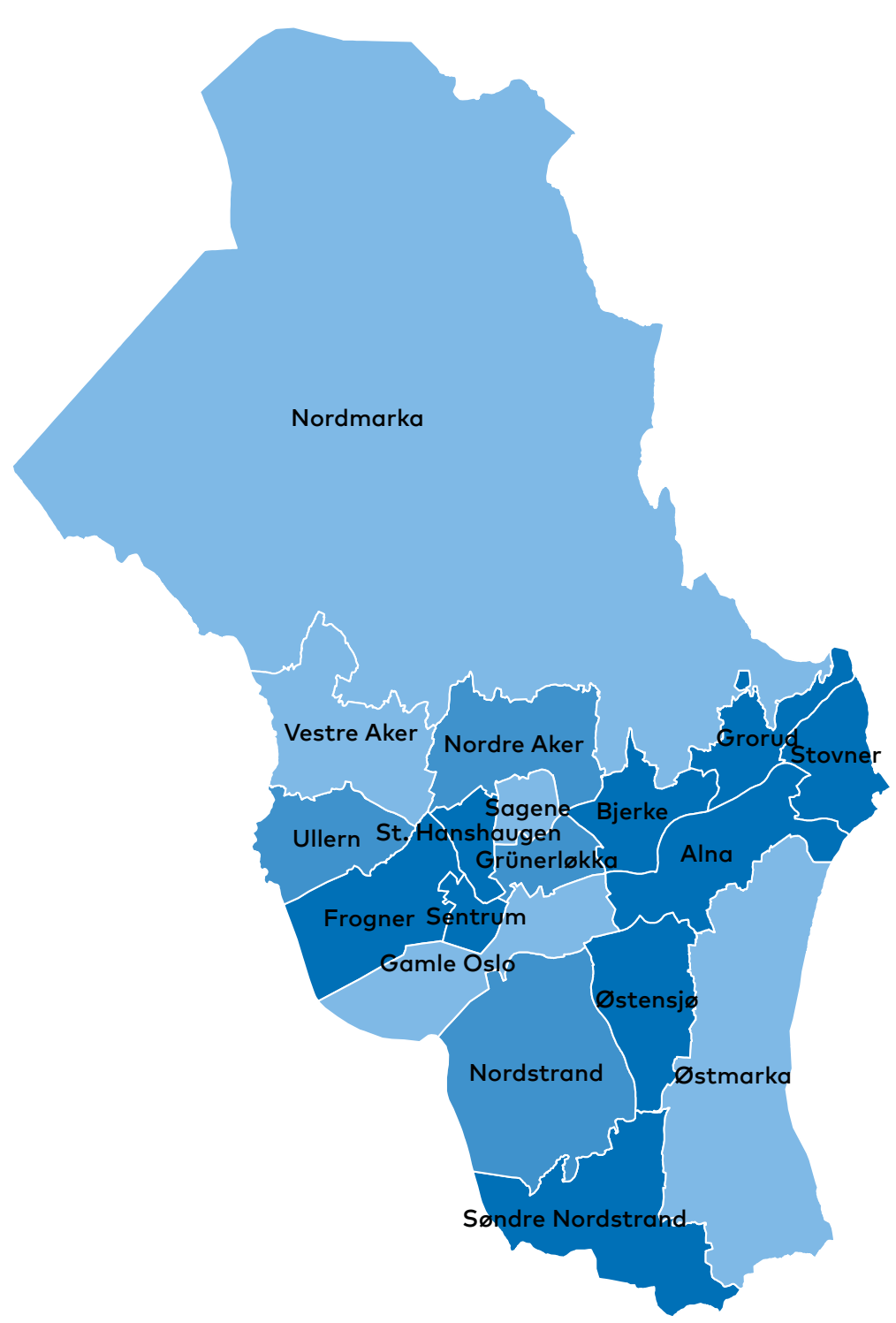

\subsection{Medelinkomst i NOK efter skatt, 2005-2015}

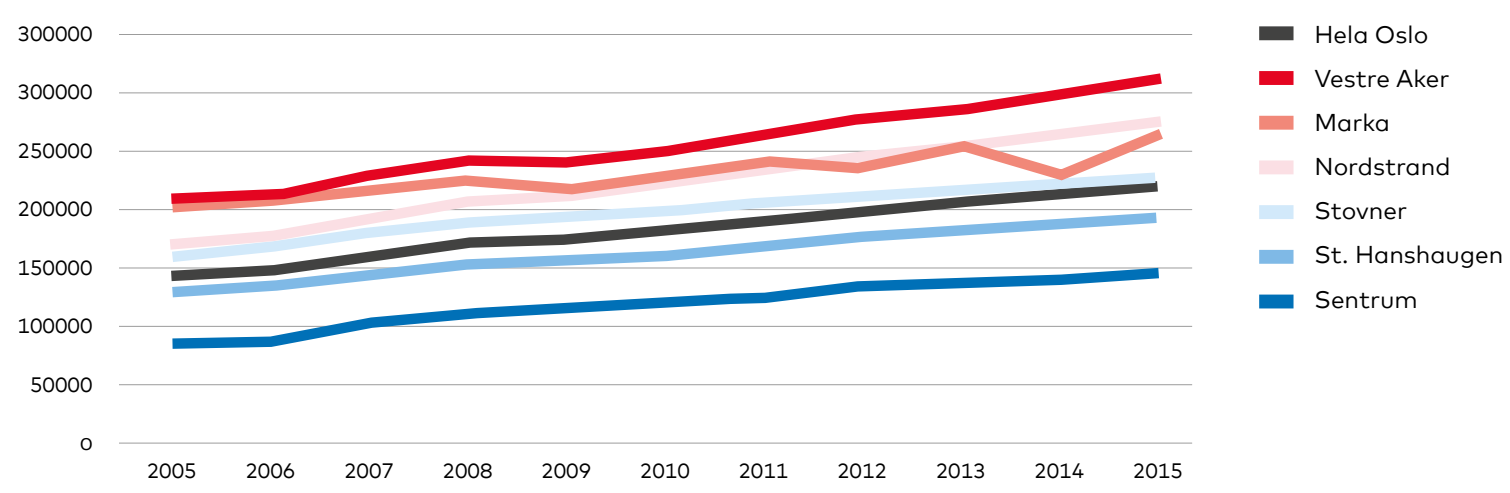

*Inkomst efter skatt avser den totala inkomsten efter skatt och negativa transfereringar. Genomsnitt i Oslo: 54,2. Källa: Oslo kommun; Öppna data Oslo. NR0372c @ Nordregio \& NLS Finland för administrativa gränser. Beskrivning av kartan och figuren, se sidan 35 
$30-40$

$40-50$

$50-60$

$>60$

60

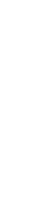

60

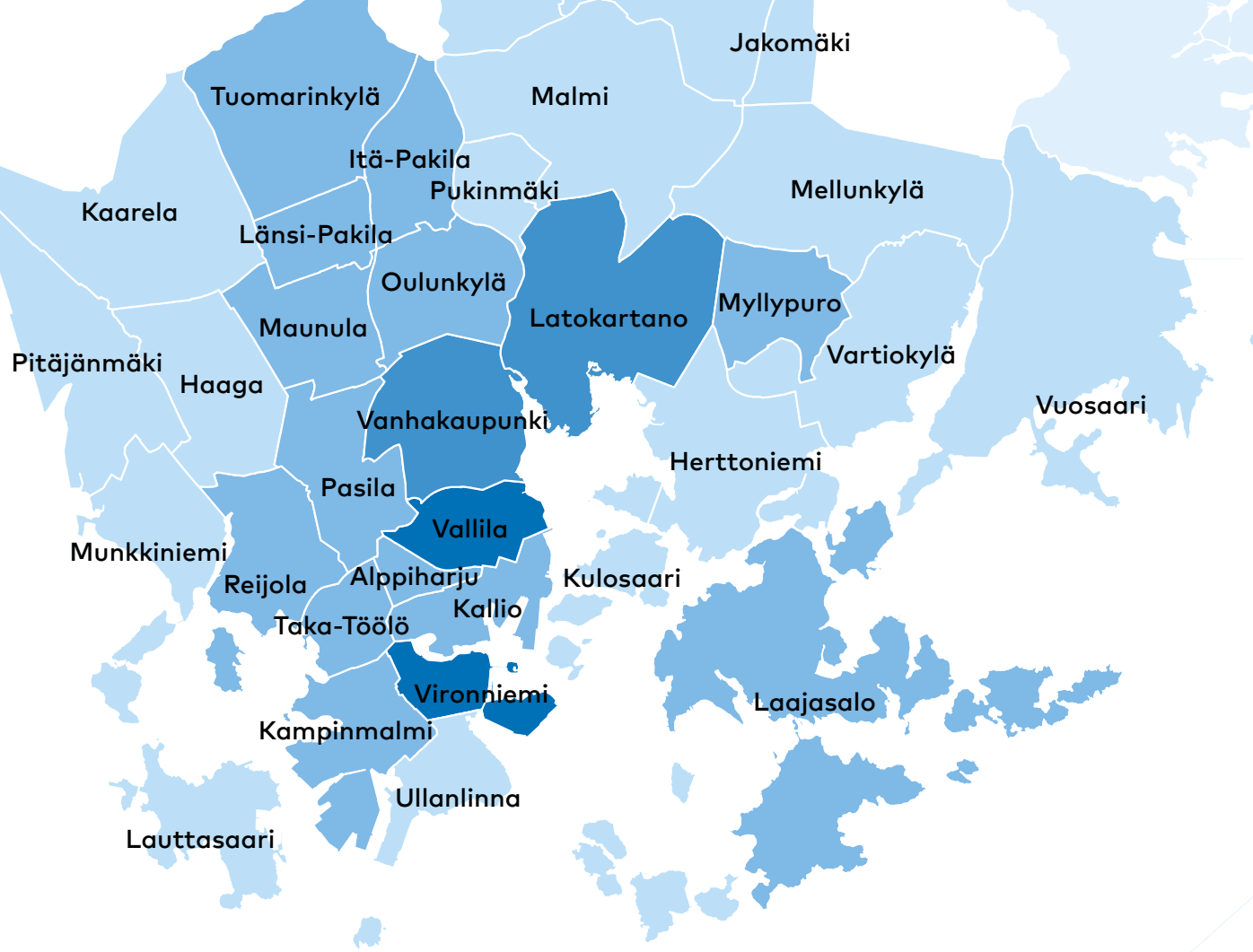

\subsection{Medelinkomst i EUR för invånare som är 15 år eller äldre, 2001-2015}

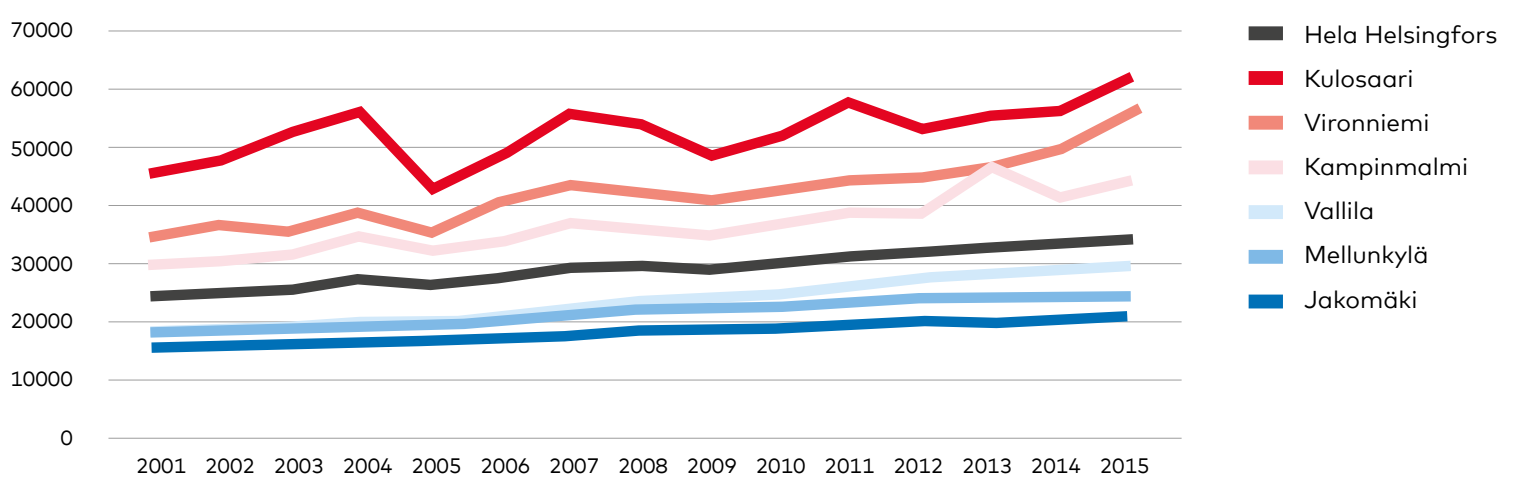




\section{Upplåtelseformer i Norden}

\begin{tabular}{|c|c|c|c|}
\hline Land & $\begin{array}{l}\text { Upplåtelseformer } \\
\text { utöver äganderätt }\end{array}$ & $\begin{array}{l}\text { Vad innebär } \\
\text { "social housing"? }\end{array}$ & $\begin{array}{l}\text { Vilka är de huvudsakliga } \\
\text { hyresvärdarna för } \\
\text { hyresrätter? }\end{array}$ \\
\hline Danmark & $\begin{array}{l}\text { Andelsbostad, allmän- } \\
\text { nyttig hyresrätt, privat } \\
\text { hyresrätt }\end{array}$ & $\begin{array}{l}\text { Allmännyttig bostad med } \\
\text { låg hyra tillgänglig för alla }\end{array}$ & $\begin{array}{l}\text { Bl.a. allmännyttiga organisa- } \\
\text { tioner och fackföreningar }\end{array}$ \\
\hline Finland & $\begin{array}{l}\text { Allmännyttig hyresrätt, } \\
\text { privat hyresrätt, en liten } \\
\text { andel delägarbostäder } \\
\text { (hyresrätt som kan övergå } \\
\text { till äganderätt), en liten } \\
\text { andel med s k bostads- } \\
\text { rätt (som är en form av } \\
\text { hyresrätt) }\end{array}$ & $\begin{array}{l}\text { Allmännyttig, behovs- } \\
\text { prövad och subventionerad } \\
\text { bostad }\end{array}$ & $\begin{array}{l}\text { Kommuner, allmännyttiga } \\
\text { organisationer, stiftelser, } \\
\text { privatpersoner (i liten skala) }\end{array}$ \\
\hline Island & $\begin{array}{l}\text { En liten andel med } \\
\text { hyresrätt, allmännyttig } \\
\text { och privat }\end{array}$ & $\begin{array}{l}\text { Äganderätt med billiga } \\
\text { bostadslån, allmännyttig } \\
\text { hyresrätt }\end{array}$ & $\begin{array}{l}\text { Kommuner, föreningar, } \\
\text { privata hyresvärdar } \\
\text { (företag, privatpersoner) }\end{array}$ \\
\hline Norge & $\begin{array}{l}\text { Privat hyresrätt, en liten } \\
\text { andel med allmännyttig } \\
\text { hyresrätt }\end{array}$ & Allmännyttig hyresrätt & $\begin{array}{l}\text { Privata hyresvärdar (företag, } \\
\text { organisationer, privatperso- } \\
\text { ner), kommuner (liten andel) }\end{array}$ \\
\hline Sverige & $\begin{array}{l}\text { Bostadsrätt, allmännyttig } \\
\text { hyresrätt och privat } \\
\text { hyresrätt }\end{array}$ & $\begin{array}{l}\text { 1) Hyresrätt och enskild } \\
\text { behovsprövad hyres- } \\
\text { subvention } \\
\text { 2) Liten andel med hyres- } \\
\text { rätt där kommunen som } \\
\text { kontraktsinnehavare. } \\
\text { Fördelas till hushåll i för- } \\
\text { söksperioder. Behovs- } \\
\text { prövade, med stränga } \\
\text { villkor }\end{array}$ & $\begin{array}{l}\text { Kommuner, privata hyresvär- } \\
\text { dar (företag, organisationer, } \\
\text { föreningar, privatpersoner) }\end{array}$ \\
\hline
\end{tabular}

De huvudsakliga skillnaderna mellan boendeformer som påverkar de nordiska ländernas segregationsmönster och relevanta åtgärder för ökad integration. För detaljerade redogörelser av de nordiska ländernas bostadspolitik, se Bengtsson et al (2013).

I Stockholm domineras marginaliserade låginkomstområden av allmännyttiga hyresrätter (Christophers 2013). Behovsprövade subventionerade bostäder av typen som återfinns $i$ Finland och Norge finns inte i Sverige, istället finns det behovsprövade bidrag till hushållen (bostadsbidrag). Christophers (2013) kallar det moderna svenska bostadssystemet för en 'monstruös hybrid' som blandar jämlikhetsarvet med en angloamerikansk nyliberalism. Han hävdar att förflyttningen mot nyliberalisering avslöjar bostadspolitikens stora betydelse för de socioekonomiska klyftorna (Christophers 2013).
Att antalet hyresrätter minskat i Sverige, och särskilt i Stockholms innerstad, har haft betydelse för gentrifieringsprocessen och har lett till att innerstadsbefolkningen till övervägande del är välbeställd och vit (Andersson \& Turner 2014). Allmännyttiga hyresrätter (och i mindre utsträckning privata hyresrätter) dominerar dock fortsättningsvis i Sveriges resurssvaga förorter (Andersson et al 2010; Lind 2015; Öresjö et al 2005). Viktigt att notera är dock att segregation och stigmatisering inte nödvändigtvis korrelerar med bostäder av låg kvalitet. 
I Danmark noterar Christensen (2015) att bostadspolitiken har bidragit till segregationen. Hyresrätter utgör ungefär 40 procent av det totala bostadsutbudet och är relativt jämnt fördelade mellan sociala bostäder (med uttryckliga subventioner och hyreskontroll, även om de inte är förbehållna låginkomsttagare) och privata hyresrätter (Andersen 2010). Trycket på subventionerade bostäder har varit stort, särskilt i Köpenhamn, och på grund av långa väntelistor är det extremt svårt för immigranter och låginkomsttagare att få tillgång till dessa bostäder. Dessutom har skillnaden i genomsnittlig hushållsinkomst mellan äganderätts- och hyressektorn ökat stadigt (Christensen 2015). Christensen (2015) pekar på de skattelättnader som ges till invånare med äganderätter som en mekanism som ytterligare förstärker klyftan på bostadsmarknaden.

Subventionerade sociala bostäder i Danmark är, trots subventionerna, i princip öppna för alla invånare. Inkomsterna är dock, med bred marginal, lägst hos personer som bor i subventionerade bostäder (Andersen 2010; Andersen et al 2013). De kämpar dessutom ofta med att komma in på den privata marknaden, och denna svårighet på bostadsmarknaden korrelerar med arbetslöshet och relativ ekonomisk fattigdom (Andersson et al 2010).

I kontrast till Sverige och Danmark är bostäderna i Norge till största delen privatägda. I landet finns endast en mycket liten andel allmännyttiga hyresrätter, som fungerar som sociala bostäder. Den totala hyressektorn utgör endast ungefär 23 procent av bostadsmarknaden, och subventionerade bostäder utgör under 5 procent av helheten. Ägarbostäder har lyfts fram politiskt som den mest önskvärda boendeformen (Andersen et al 2013). Detta indikerar att Norge har den mest stratifierade bostadsmarknaden av alla nordiska länder och att mobiliteten är låg. Andersen et al (2013) noterar att detta kan leda till diskriminering, eftersom immigranter och etniska minoriteter har svårt att få tillgång till bostäder och ofta behöver stå ut med trångboddhet och otrygghet (Andersen et al 2013).

I Finland visar forskning om migration i Helsingforsregionens stadsdelar under 2000-talet (t.ex. Dhalmann et al 2013; Vilkama 2011; Vilkama
\& Vaattovaara, 2015) att den nya geografiska strukturen som etablerats i regionen med avseende på sociala och etniska skillnader är relaterad till migration. Tecken på selektiv migration har observerats, och man har studerat orsaker till att den infödda medelklassens lämnar eller bor kvar i socioekonomiskt eftersatta stadsdelar (Dhalmann et al 2013; Vilkama \& Vaattovaara 2015). Även invandrargruppers bostadspreferenser har undersökts (t.ex. Dhalmann, 2013). Precis som i övriga nordiska huvudstäder är Helsingfors invånare med utländsk bakgrund koncentrerade i låginkomstområden med en hög andel hyresrätter (Vilkama, 2011).

\section{I kontrast till Sverige och Danmark är bostäderna $i$ Norge till största delen privatägda. I landet finns endast en mycket liten andel allmännyttiga hyresrätter, som fungerar som sociala boståder}

År 2002 lade Kauppinen fram hypotesen att subventionerade sociala bostäder förklarar invandrares bosättningsmönster $\mathrm{i}$ staden och varnade för att de riskerade att så att säga bli fast i den typen av bostäder (Kauppinen 2002). Vaattovaara och Kortteinen (2012) påpekar att Helsingfors skiljer sig från andra europeiska städer genom att fattigdom och socialt utanförskap ofta är koncentrerade i specifika byggnader eller kvarter, istället för hela stadsdelar. De ser detta som en följd av den systematiska sociala blandningspolitik som Helsingfors stad har tillämpat sedan 1960-talet, där man blandar upplåtelseformer. Istället för att utgöra en reaktiv segregationsmotverkande politik anses denna blandningspolitik i högre grad vara förebyggande (Dhalmann \& Vilkama 2009). 


\section{Bostäder för \\ flyktingar och asylsökande}

En annan bostadspolitisk fråga av betydelse för bostadssegregationen är bosättningspolitiken för flyktingar och asylsökande, och huruvida och hur bostäder fördelas till dem som får uppehållstillstånd. Enligt Andersson et al (2010) finns det några avgörande skillnader. En konsekvens av det svenska systemet där flyktingar och asylsökande kunnat bosätta sig var de vill om de ordnat med eget boende (den så kallade EBO-lagen) har varit att många immigranter har flyttat till de större städerna och bor under trånga förhållanden (Boverket 2015; Myrberg 2012). Det har visat sig att EBO-systemet $i$ Sverige är helt beroende av boende hos släktingar och olagliga andrahandskontrakt (Boverket 2015), och detta är ett problem som anses påverka den sociala hållbarheten i städer på lång sikt. År 2015 publicerade Boverket en rapport om bostadsförhållanden för nyanlända flyktingar och asylsökande som ordnar med eget boende (Boverket 2015). Baserat på kommunala fallstudier drog de slutsatsen att de sociala konsekvenserna i många fall är mycket negativa och att förändringar är nödvändiga beträffande såväl rätten att ordna med eget boende som, ur ett bredare perspektiv, statens roll att tillhandahålla bostäder till rimliga kostnader. I en utredning som lades fram 2018 föreslås att asylsökandes möjligheter till eget boende begränsas genom att kommuner med socialt och ekonomiskt utsatta stadsdelar får genomföra en social prövning (SOU 2018:22).
Norges system påminner om Sveriges i det att immigranter är fria att bosätta sig var de vill om de kan försörja sig och hitta bostad (Andersson et al 2010). De riskerar dock att förlora sin ekonomiska ersättning om de bosätter sig i en annan kommun än den de placerats i.

\section{En konsekvens av de danska och finska systemen är en hög koncentration av invandrare i subventionerade sociala bostäder}

I Danmark och Finland fördelas asylsökande som fått uppehållstillstånd till vissa kommuner för att skapa en jämn fördelning istället för en koncentration i vissa städer, kommuner eller stadsdelar. De danska lokala myndigheterna är sedan skyldiga att tilldela flyktingen en permanent bostad, ofta i form av subventionerade sociala bostäder (Andersson et al 2010). Jämfört med Sverige utövar Finland och Danmark större kontroll över kommunerna, men detta innebär även en situation med större begränsningar för individen. En konsekvens av de danska och finska systemen är en hög koncentration av invandrare i subventionerade sociala bostäder (Andersson et al 2010). 


\section{Grannskapseffekter och den byggda miljöns utformning}

I Sverige har Legeby $(2010 ; 2011 ; 2013)$ skrivit mycket om utmaningarna som rör den byggda miljön och tillgängligheten till arbetsplatser och tjänster i resurssvaga stadsdelar. Hennes arbete fokuserar på synliga fysiska faktorer och hon kombinerar så kallad space syntax-teori med rumslig analys och information från enkäter och observationer. Mer specifikt visar hennes arbete att Stockholms resurssvagaste områden ligger långt från arbetsmöjligheter, långt från stadens centrum och ofta långt från centrala samhälleliga och sociala arenor, vilket leder till en negativ effekt på det lokala samhällslivet (Legeby 2011).

Utöver den här typen av tillgänglighetsaspekter berör mycket av litteraturen om segregation grannskapseffekter. Detta begrepp syftar på hur invånarna kan påverkas av att bo i en viss typ av område. Om möjligheter till arbete, utbildning och social rörlighet minskar av att bo i ett visst område kan segregation och social isolering förstärka och vidmakthålla varandra. I kontrast till detta kan förstås även över- och medelklassområden vidmakthållas på samma sätt och bli allt mer homogena och välbärgade över tid.

Vid bedömningen av grannskapseffekter på Island använder Valdimarsdóttir och Bernburg (2015) en befolkningsundersökning för att fastställa effekten av sociala band på stadsdelsnivå på brottslighet och efterlevnad av sociala normer. Deras resultat tyder på att brottsligheten bland tonåringar som bor i utsatta områden ("neighbourhoods characterized by concentrated disadvantage") är högre. Detta efter att man korrigerat för andra faktorer (Valdimarsdóttir och Bernburg 2015). Vid en statistisk analys av grannskapseffekter inom utbildning i Helsingfors drog dock Kauppinen (2007) en annan slutsats, som tydde på att det inte fanns några grannskapseffekter gällande om unga i Helsingfors slutför gymnasiet eller ej (Kauppinen 2007). Han identifierar istället koncentrationen av välstånd som den viktigaste faktorn.

I en fallstudie av Osloförorten Sandvika i Norge försöker Røe (2014) sätta ord på kopplingen mellan fysisk stadsplanering och det mer abstrakta skapandet av en plats och dess identitet. Røe (2014) vittnar om att planerarna missade viktiga sociokulturella aspekter som rör platsen eftersom kommunens planering ledde till en stark tonvikt på fysisk utformning och brist på medborgardeltagande. Även om tillgången till lokal service förstås är viktig medför detta fokus på fysiska och synliga aspekter som ett sätt att nå jämlikhet och hållbarhet flera risker (Røe 2014). I synnerhet finns det en risk att man främjar gentrifiering och intensifierar segregerande flyttmönster genom att behandla en komplicerad fråga som segregation som något kopplat till attraktiva platser eller arkitektur. 
På ett liknande sätt noterar Dhalmann \& Vilkama (2008) att etnisk boendesegregation i Finland främst setts som ett rumsligt problem. Det har avlett uppmärksamheten från strukturella samhälleliga hinder (Dhalmann \& Vilkama 2008). Trots erkännandet från det finska planeringsväsendet att etnisk och socioekonomisk segregation är ett problem, har man i begränsad omfattning erkänt betydelsen av diskriminering och strukturella barriärer.

\section{Stockholms resurssvagaste områden ligger långt från arbetsmöjligheter, långt från stadens centrum och ofta långt från centrala samhälleliga och sociala arenor}

I en studie av ett ambitiöst stadsförnyelseprojekt i en relativt resurssvag stadsdel i Köpenhamn (Indre Vesterbro) i Danmark ifrågasätter Larsen och Hansen (2008) de goda intentionerna i ett stadsutvecklingsprojekt med hållbarhetsambitioner. Ovanligt nog rörde deras fallstudie ett upprustningsprojekt som uttryckligen var inriktat mot sociala frågor och en process där invånarna hjälpte till att ta fram nya planer
(Larsen \& Hansen 2008). Resultatet var dock en gentrifiering av området. Bostadspriserna ökade dramatiskt i Vesterbro i takt med upprustningen och många av de ursprungliga invånarna blev tvungna att flytta till följd av de höjda bostadspriserna.

De studier som beskrivits här pekar på en av de största konflikterna som stadsplanerare kan stöta på när de försöker arbeta för att motverka segregation. Genom att försöka göra områden mer attraktiva riskerar man att göra segregationen och ojämlikheten i staden ännu större.

Detta kunde vara ett argument för mer småskaliga och socialt inriktade insatser, som kanske inte ersätter en långsiktig strategisk stadsutveckling, men i alla fall kompletterar den. Till exempel är det möjligt att motverka gentrifiering genom att fokusera på att skapa icke-kommersiella mötesplatser, såsom platser för utbildning, kulturevenemang eller andra sociala aktiviteter. 


\section{Diskriminering och stigmatisering}

Katisko (2015) argumenterar för att politiken rörande invandring också måste vara en stadsplaneringspolitik och betonar den nära kopplingen mellan invandrares ofta ogynnsamma omständigheter och stadspolitiken. Denna tanke kanske inledningsvis låter provocerande, men den baseras på en förståelse av att olika grupper har fundamentalt olika upplevelser och fördelar av stadens rum. Till exempel menar både Legeby (2013) och Schierup et al (2014) att segregation var de huvudsakliga orsakerna till att upplopp utbröt i Stockholm 2013. Invandring, diskriminering och stigmatisering är också nära sammankopplade med segregation. Detta beror delvis på att många ogynnsamma omständigheter är koncentrerade till grupper med invandrarbakgrund, och delvis på att problematisering av mer välbeställda eller privilegierade gruppers handlingar saknas. Dessutom har flyktingkrisen och den politiska förflyttningen högerut i de flesta nordiska länder skapat en diskurs där invandrare och icke-vita populationer ofta stigmatiseras som icke-önskvärda eller en börda för samhället (Andersson 2013; Hübinette 2014; Hübinette och Lundström 2014; Jørgensen 2015).

När Larsen och Hansen (2008) skriver om Köpenhamn i Danmark noterar de en bekymmersam diskurs som genomsyrar diskussionen om invandrare och minoriteter i staden. Låginkomstgrupper, och särskilt sådana med utländsk bakgrund,

kallas informellt för stadens 'skräp', och det finns

\section{Lo̊ginkomstgrupper, och särskilt sådana med utländsk bakgrund, kallas informellt för stadens "skräp", och det finns en underförstådd koppling mellan utlänningar och problem}

en underförstådd koppling mellan utlänningar och problem. Det finns dessutom bostadsområden i Danmark som i den offentliga diskursen kallas 'ghetto'. Den danska regeringen har en så kallad 'ghettolista' som uppdateras varje år, och på den listas områden med hög andel boende som är arbetslösa, har låg utbildning och inkomst, finns i brottsregistret och har ickevästlig etnisk bakgrund. Jørgensen (2015) anser att denna beteckning av låginkomstområden som getton är stigmatiserande och oansvarigt använd, och att den förstärker befintliga mönster av segregation och diskriminering.

Det finns tecken på att etnisk diskriminering begränsar minoritetsgrupper tillgängliga alternativ på bostadsmarknaden, både i Sverige och Norge (Ahmed och Hammarstedt 2008; Bengtsson et al 2012). Hübinette och Lundström (2014) lyfter 
fram kopplingen mellan strukturell rasism och segregation i Sverige, och hävdar att en kraftfull diskurs i landet förhindrar "avskiljandet av svenskhet från vithet". De hävdar att en del av svårigheterna på arbetsmarknaden och segregationen i svenska städer kan förklaras genom exkludering och diskriminering i det svenska samhället. Allmänt fientliga attityder från majoritetsbefolkningen kan också motivera invandrare och personer med utländsk bakgrund till att så att säga 'segregera sig' på eget initiativ (Dhalmann \& Vilkama 2008).

Slutligen finns det tendenser till en white flight, liknande den i USA, som bidrar till både etnisk och socioekonomisk segregation. Aldén et al (2014) menar att det finns brytpunkter där andelen utomeuropeiska invandrare ökar och ökningen av den infödda svenska befolkningen $i$ en stadsdel går ner (Aldén et al 2014).

Dessa resultat tyder på att områdesbaserade åtgärder inriktade på 'problemområden' och svaga grupper kanske inte är tillräckligt för att motverka inföddas flyttmönster, och att segregationsproblem måste diskuteras som ett problem för staden i sin helhet. Även om områdesbaserade åtgärder och grannskapseffekter, som tagits upp ovan, ses med viss skepticism inom forskningen (se även Urban 2017), måste dock en integrerad stad ha rum och platser där integrationen kan ta plats: offentliga rum, lokalsamhällen och rum för social samvaro. Planeringen av den lokala byggda miljön har därmed definitivt en betydelse. Det behöver dock finnas en medvetenhet om skillnaden mellan lokala problem och lokala lösningar samt de problem och lösningar som måste hanteras av hela staden eller samhället, och som omfattar lagar, nationell politik och långsiktig stadsplanering. 


\section{Hela staden är segregerad}

Den här översikten har tagit upp flera olika sätt att förstå segregationen i nordiska städer, och pekat på några specifika områden där det behövs, och också redan sätts in, åtgärder. Dessa rör bostadspolitikens område där det är avgörande att sänka barriärerna på bostadsmarknaden och öka tillgången till bostäder till rimliga kostnader. De rör även den fysiska planeringen som kan bidra till skapandet av mötesplatser där fysiska, ekonomiska, kulturella och sociala barriärer mellan människor och grupper kan överbryggas, och slutligen rör de problem med diskriminering av människor och stigmatisering av stadsdelar och bostadsområden.

Inledningsvis lyftes också lokalsamhällets betydelse när det gäller den integrerade staden. Det är där bostadspolitiken och segregationen blir tydlig och det är där det är viktigt att det finns tillgång till service, utbildning, offentliga rum, mötesplatser och så vidare.

\section{Man måste se segregation som ett problem för hela staden, där även segregationen av den resursstarka befolkningen har stor betydelse}

En hel del forskning är också kritisk till det lokala fokuset i mycket av insatserna mot segregation, och det lyfts mer och mer fram att man måste se segregation som ett problem för hela staden, där även segregationen av den resursstarka befolkningen har stor betydelse, liksom gentrifiering. En annan viktig slutsats vi kan dra av den här översikten är att för att skapa mer integrerade städer så är det många olika aktörer som måste göra insatser - kommuner, bostadsbolag, lokala föreningar och företag. 


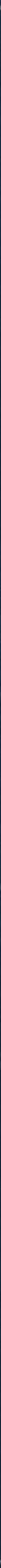




\section{Kartor och figurer}

SID 9

1. Kartan visar förändring av befolkningsandel med utländsk bakgrund $i$ Stockholm på områdesnivå. Färgnyansen representerar ökningen av befolkningsandel med utländsk bakgrund $\mathrm{i}$ procent mellan åren 2003 och 2016. Ju mörkare färg, desto större ökning av befolkningsandel med utländsk bakgrund. Kartan visar ett tydligt mönster, med de största ökningarna i de västra områdena (Hässelby-Vällingby och Skärholmen) och de minsta ökningarna $\mathrm{i}$ innerstaden och i östra Stockholm. Den genomsnittliga ökningen av befolkningsandel med utländsk bakgrund i Stockholms kommun är 5,1 procent.

1.1. Figuren längst ner visar stora skillnader mellan Stockholms olika områden, med den största andelen över 70 procent (Rinkeby-Kista) och den minsta andelen under 20 procent (Södermalm) under 2016. Den växande trenden har dock observerats i alla områden.
SID 10

2. Kartan visar förändring av befolkningsandel med utländsk bakgrund i Köpenhamn på områdesnivå. Färgnyansen representerar ökningen av befolkningsandel med utländsk bakgrund $\mathrm{i}$ procent mellan åren 2000 och 2017. Ju mörkare färg, desto större ökning av befolkningsandel med utländsk bakgrund. Kartan visar ett tydligt mönster, med de största ökningarna i norra Köpenhamn (Brønshøj-Husum osv.) och de minsta ökningarna i det centrala området Nørrebro. Den genomsnittliga ökningen av befolkningsandel med utländsk bakgrund i Köpenhamns kommun är 7,3 procent.

2.1. Figuren längst ner visar stora skillnader mellan Köpenhamns olika områden, men den ökande trenden gäller för hela staden.
SID 11

3. Kartan visar förändring av befolkningsandel med utländsk bakgrund i Oslo på områdesnivå. Färgnyansen representerar ökningen av befolkningsandel med utländsk bakgrund i procent mellan åren 2000 och 2016. Ju mörkare färg, desto större ökning av befolkningsandel med utländsk bakgrund. Kartan visar ett tydligt mönster, med de största ökningarna $\mathrm{i}$ östra och södra Oslo, och de minsta ökningarna i det centrala området Gamle Oslo. Nord- och Østmarka består till stor del av naturområden och har väldigt få bostadsområden och invånare. Den genomsnittliga ökningen av befolkningsandel med utländsk bakgrund i Oslo kommun är 13,9 procent.

\subsection{Figuren längst ner} visar stora skillnader mellan Oslos olika områden, med den högsta befolkningsandelen runt 50 procent och den lägsta runt 10 procent år 2016, men den ökande trenden gäller för hela staden.
SID 12

4. Kartan visar förändring av befolkningsandel med utländsk bakgrund $i$ Helsingfors på områdesnivå. Den röda färgen representerar en minskning av befolkningsandelen med utländsk bakgrund $\mathrm{i}$ procent mellan åren 2011 och 2017. Den blå färgen representerar en ökning. Ju mörkare nyans, desto större ökning. Kartan visar ett tydligt mönster, med de största ökningarna $i$ de västra områdena (Jakomäki och Mellunkylä), de minsta ökningarna i innerstaden och en minskning i södra Helsingfors (Vironniemi och Ullanlinna). Den genomsnittliga ökningen av befolkningsandel med utländsk bakgrund i Helsingfors kommun är 4,2 procent.

4.1. Figuren längst ner visar stora skillnader mellan Helsingfors olika områden. År 2017 var den högsta befolkningsandelen runt 30 procent (i Jakomäki) och den lägsta runt 5 procent (i Tuomarinkylä). 
5. Kartan visar förändring i medelinkomst i Stockholms kommun per område mellan 2005 och 2015. Inkomst avser den totala inkomsten. Färgnyansen representerar ökningen över en tioårsperiod. Ju mörkare nyans, desto större ökning av medelinkomsten. Kartan visar ett tydligt mönster, med de högsta nivåerna i centrala områden (Norrmalm osv.) och de lägsta nivåerna i ytterområdena. Den genomsnittliga medelinkomsten i Stockholms kommun steg med 35,1 procent under tidsperioden och siffrorna från Stockholms södra områden ligger nära genomsnittet.

5.1. Figuren längst ner visar stora skillnader mellan de olika områdena, men den ökande trenden gäller för alla områden.
6. Kartan visar förändring $\mathrm{i}$ disponibel medelinkomst i Köpenhamns kommun per område mellan 2000 och 2015. Färgnyansen representerar ökningen mellan 2000 och 2015. Ju mörkare nyans, desto större ökning av disponibel medelinkomst. Kartan visar ett tydligt mönster, med de högsta nivåerna i Köpenhamns sydöstra områden, och de lägsta nivåerna i de norra områdena. Den genomsnittliga ökningen av disponibel medelinkomst i Köpenhamns kommun är 65,4 procent.

6.1. Figuren längst ner visar stora skillnader mellan Indre By (högsta inkomstnivå) och andra områden, men den ökande trenden gäller för alla områden.
7. Kartan visar förändring i medelinkomst i Oslo kommun per område mellan 2005 och 2015. Färgnyansen representerar ökningen under perioden. Ju mörkare nyans, desto större ökning av medelinkomsten. Kartan visar ett tydligt mönster, med de högsta nivåerna i de centrala områdena och de lägsta nivåerna i ytterområdena. Den genomsnittliga ökningen av medelinkomst i Oslo kommun är 52,4 procent.

7.1. Figuren längst ner visar stora skillnader mellan centrala Oslo och övriga områden, men den ökande trenden gäller för hela staden.
8. Kartan visar förändring i medelinkomst i Helsingfors kommun per område mellan 2001 och 2015. Färgnyansen representerar ökningen mellan 2001 och 2015. Ju mörkare nyans, desto större ökning av medelinkomst. Kartan visar ett tydligt mönster med de högsta nivåerna i de centrala områdena och de lägsta nivåerna i ytterområdena. Den genomsnittliga ökningen av medelinkomst i Helsingfors kommun är 39,8 procent.

8.1. Figuren längst ner visar en ökande trend som gäller för hela staden, men med stora skillnader mellan de olika områdena. Vissa områden drabbades hårdare av den ekonomiska krisen år 2008. Data för Östersundom gäller för åren 2008-2015. 
Ahmed, A. M., \& Hammarstedt, M. (2008).

Discrimination in the rental housing market: a field experiment on the Internet. Journal of Urban Economics, 64(2), 362-372.

Aldén, L., \& Hammarstedt, M. (2014). Integration of immigrants on the Swedish labour market: recent trends and explanations. Centre for Labour Market and Discrimination Studies, Linnaeus University.

Aldén, L., Hammarstedt, M., \& Neuman, E. (2014).

Ethnic segregation, tipping behavior, and native residential mobility. International Migration Review, 49(1), 36-69.

Andersen, H. S. (2010).

Contextualizing ethnic residential segregation in Denmark: welfare, housing and immigration.

Danish Building Research Institute, Aalborg University.

Andersen, H. S., Turner, L. M., \& Søholt, S. (2013).

The special importance of housing policy for ethnic minorities: evidence from a comparison of four Nordic countries. International Journal of Housing Policy, 13(1), 20-44.

Andersson, R. (2013).

Reproducing and reshaping ethnic residential segregation in Stockholm: the role of selective migration moves. Geografiska Annaler: Series B, Human Geography, 95(2), 163-187.

Andersson, R., \& Turner, L. M. (2014). Segregation, gentrification, and residualisation: from public housing to market-driven housing allocation in inner city Stockholm. International Journal of Housing Policy, 14(1), 3-29.
Andersson, R., Dhalmann, H., Holmqvist, E., Kauppinen, T., Turner, L., Andersen, H., Soholt, S., Vaattovaara, M., Vilkama, K., Wessel, T., Yousfi, S. (2010). Immigration, Housing and Segregation in the Nordic Welfare States. NODES Research Output. University of Helsinki.

Bengtsson, B. (ed.) (2013). Varför så olika? Nordisk bostadspolitik i jämförande historiskt ljus. Malmö: Égalité.

Bengtsson, R., Iverman, E., \& Hinnerich, B. T. (2012). Gender and ethnic discrimination in the rental housing market.

Applied Economics Letters, 19(1), 1-5.

Bernelius, V. (2013).

Eriytyvät kaupunkikoulut. Helsingin peruskoulujen oppilaspohjan erot, perheiden kouluvalinnat ja oppimistuloksiin liittyvät aluevaikutukset osana kaupungin eriytymiskehitystä.

Tutkimuksia 1:2013. Helsingin kaupungin tietokeskus. Available at:

https://helda.helsinki.fi/

Boverket (2015).

Boendesituationen för nyanlända, rapport 2015:40. Karlskrona: Boverket.

Bunar, N. (2010).

Choosing for quality or inequality: current perspectives on the implementation of school choice policy in Sweden. Journal of Education Policy, 25(1), 1-18.

Christensen, G. (2015). A Danish tale of why social mix is so difficult to increase. Housing Studies, $30(2), 252-271$.
Christophers, B. (2013).

A monstrous hybrid: the political economy of housing in early twenty-first century Sweden. New Political Economy, 18(6), 885-911.

Dhalmann, H. (2013).

Explaining ethnic residential preferences - The case of Somalis and Russians in the Helsinki Metropolitan Area. Housing Studies, 28(3), 389-408.

Dhalmann, H., \& Vilkama, K. (2009). Housing policy and the ethnic mix in Helsinki, Finland: perceptions of city officials and Somali immigrants. Journal of Housing and the Built Environment 28(3), 389-408.

Dhalmann, H., Vaattovaara, M., \& Vilkama, K. (2013).

Hyvää kasvuympäristöä etsimässä. Asuinalueen ja koulun merkitys lapsiperheiden muuttopäätöksille pääkaupunkiseudulla.

Yhdyskuntasuunnittelu 51 (2013): 4.

\section{ESPON (2014).}

TIPSE: Territorial dimension of poverty and social exclusion in Europe.

Available at: www.espon.eu

Hübinette, T. (2014).

Challenging the rumours in Botkyrka

- Facts and argumentation.

Botkyrka kommun.

Hübinette, T., \& Lundström, C. (2014). Three phases of hegemonic whiteness: understanding racial temporalities in Sweden. Social Identities, 20(6), 423-437.

Jørgensen, M. (2015).

Research-Policy Dialogues in Denmark. In Scholten, P., Entzinger, H., Pennix, R., Verbeek, S. (Eds). Integrating Immigrants in Europe: Research-Policy Dialogues, (pp 275-292) London: Springer International Publishing. 
Katisko, M. (2015)

Homelessness among immigrant youth: transitions between inclusion and exclusion. European Journal of Homelessness, Volume 9(1), 61-76.

Kauppinen, T. M. (2002).

The beginning of immigrant settlement in the Helsinki metropolitan area and the role of social housing. Journal of Housing and the Built Environment, 17(2), 173-197.

Kauppinen, T. M. (2007).

Neighborhood effects in a European city: secondary education of young people in Helsinki. Social Science Research, 36(1), 421-444.

Kortteinen, M., \& Vaattovaara, M. (2007). Miten Helsingin käykään? Yhteiskuntapolitiikka 72 (2007):2.

Larsen, H. G., \& Hansen, A. L. (2008). Gentrification - gentle or traumatic? Urban renewal policies and socioeconomic transformations in Copenhagen. Urban Studies, 45(12), 2429-2448.

Legeby, A. (2010).

From housing segregation to integration in public space.

The Journal of Space Syntax, 1(1), 92-107.

Legeby, A. (2011).

Limited permeability in the enclaved city. In Eighteenth International Seminar on Urban Form, Montréal, Canada.

Legeby, A. (2013).

Configuration and co-presence: the underpinnings of job opportunities. In 2013 International Space Syntax Symposium; Seoul, Korea 31 October-3 November, 2013. Sejong University.
Lilja, M. (2015).

"Det bästa för mitt barn":

nyblivna mödrar i den delade staden.

Örebro: Örebro University.

Lind, H. (2015).

A monstrous hybrid: A comment on Brett Christophers' interpretation of Swedish housing policy. Working Paper 2015:04, Department of Real Estate and Construction Management, School of Architecture and the Built Environment, KTH Royal Institute of Technology.

Lödén, H. (2008).

Swedish: being or becoming? Immigration, national identity and the democratic state. International Journal of Social Sciences, 3(4), 257-264.

Marcińczak, S., Musterd, S., van Ham, M., Tammaru, T. (2015). Inequality and rising levels of socio-economic segregation. In Marcińczak, S., Musterd, S., van Ham, M., Tammaru, T. (eds). Socio-Economic Segregation in European Capital Cities: East meets West (pp 358-328). Oxford: Routledge.

Myrberg, Gunnar (2012).

Var ska de nyanlända bo? Perspektiv från Malmö och Århus på svensk och dansk flyktingplaceringspolitik.

Stockholm: Institutet för framtidsstudier.

Poikolainen, J. (2012).

A case study of parents' school choice strategies in a Finnish urban context. European Educational Research Journal, 11(1), 127-144.

Rangvid, B. S. (2007). Living and learning separately? Ethnic segregation of school children in Copenhagen. Urban Studies, 44(7), 1329-1354.
Rodenstedt, A. (2014).

Living in the calm and safe part of the city: the socio-spatial reproduction of upper-middle class neighbourhoods in Malmö. Geographica 6. Department of Social and Economic Geography, Uppsala University.

Røe, P. G. (2014).

Analysing place and place-making: urbanization in suburban Oslo. International Journal of Urban and Regional Research, 38(2), 498-515.

Schierup, C. U., Ålund, A.

\& Kings, L. (2014).

Reading the Stockholm riots

- a moment for social justice?

Race \& Class, 55(3), 1-21.

Seppänen, P. (ed.) (2015).

Lohkoutuva peruskoulu: perheiden kouluvalinnat, yhteiskuntaluokat ja koulutuspolitiikka. Kasvatusalan tutkimuksia 1458-1094;68.

Sindradóttir, J., \& Júlíusdóttir, M. (2008). 'Búseta innfl ytjenda á höfuðborgarsvæðinu'. LANDABRÉFIĐ 24.

SOU 2018:22. Ett ordnat mottagande: gemensamt ansvar för snabb etablering eller återvändande. Betänkande av Mottagandeutredningen.

Szulkin, R., \& Jonsson, J. O. (2007). Ethnic segregation and educational outcomes in Swedish comprehensive schools. Stockholm University Linnaeus Center.

Søholt, S., Ruud, M. E. \& Braathen, E. (2012).

A question of social sustainability: urban interventions in critical neighbourhoods in Portugal and Norway. Urban Research \& Practice, 5(2), 256-272. 
Trumberg, A. (2011)

Den delade skolan: Segregationsprocesser $i$ det svenska skolsystemet. Örebro: Örebro University.

Turner, L. M., \& Wessel, T. (2013). Upwards, outwards and westwards: relocation of ethnic minority groups in the Oslo region. Geografiska Annaler: Series B, Human Geography, 95(1), 1-16.

Urban, S. (2017).

Vad spelar det för roll var du bor? In Adenfelt, O. \& Bergström, A. (eds). Hela staden - bryt segregationen.

Stockholm: Fores.

Vaattovaara, M.,

\& Kortteinen, M. (2012).

Segregaatiosta ja sen inhimillisestä ja yhteiskunnallisesta merkityksestä. Talous \& yhteiskunta, 40, 3-60.

Valdimarsdóttir, M.,

\& Bernburg, J. G. (2015).

Community disadvantage, parental network, and commitment to social norms: multilevel study of selfreported delinquency in Iceland. Journal of Research in Crime and Delinquency, 52(2), 213-244.

Wessel, T. (2013).

Economic change and rising income inequality in the Oslo region: the importance of knowledge-intensive business services. Regional Studies, 47(7), 1082-1094.

Wessel, T. (2015).

Economic segregation in Oslo: polarisation as a contingent outcome. Pp 132-155 in: Socio-Economic Segregation in European Capital Cities: East Meets West, Marcińczak, S., Musterd, S., van Ham, M.,

Tammaru, T. (Eds). Oxford: Routledge.
Vilkama, K. (2011).

Yhteinen kaupunki, eriytyvät kaupunginosat? Kantaväestön ja maahanmuuttajataustaisten asukkaiden alveellinen eriytyminen ja muuttoliike pääkaupunkiseudulla. Tutkimuksia 2/2011. Helsingin kaupungin tietokeskus.

Vilkama, K., \& Vaattovaara, M. (2015).

Keskiluokka kuin kotonaan? Kokemuksia sosioekonomisesti heikoimmilla alueilla asumisesta pääkaupunkiseudulla. Yhteiskuntapolitiikka 80 (2015):3.

Vilkama, K., Lönnqvist, H., VäliniemiLaurson, J., \& Tuominen, M. (2014). Erilaistuva pääkaupunkiseutu Sosioekonomiset erot alveittain 2002 -2012. Tutkimuksia 1/2014. Helsingin kaupungin tietokeskus.

Åslund, O., Östh, J., \& Zenou, Y. (2010).

How important is access to jobs? Old question - improved answer. Journal of Economic Geography, 10(3), 389-422.

Öresjö, E., Pettersson, L., Holmqvist, E., Siwertsson, C., \& Solid, D. (2005). Large housing estates in Stockholm and Jönköping, Sweden: opinions of residents on recent developments. Faculty of Geosciences,

Utrecht University.

Östh, J., Clark, W. A., \& Malmberg, B. (2015).

Measuring the scale of segregation using k-nearest neighbor aggregates. Geographical Analysis, 47(1), 34-49. 

Nordiska ministerrådet

Nordens Hus

Ved Stranden 18

DK-1061 Köpenhamn K

www.norden.org

\section{Den segregerade staden}

Problem som rör segregation och integration utgör viktiga ansvarsområden och utmaningar för städer, en segregerad stadsmiljö kan ses som ett symtom på sociala orättvisor i vidare bemärkelse. I denna kortfattade översikt av aktuell forskning om boendesegregation ligger fokus på strukturella orsaker till segregationen.

Det innebär att det snarare är planeringspolitik och tendenser i den socioekonomiska utvecklingen som diskuteras, istället för specifika åtgärder och projekt för social integration. Det finns dock en självklar arena där dessa två syner på segregation möts, och det är i lokalsamhället och dess rum och platser för social samvaro.

Det är viktigt att komma ihåg, att den integrerade staden är ett resultat av såväl strategier och initiativ på mikronivå, i grannskap och mellan individer, som av initiativ och utveckling på makronivå.

Den här rapporten ingår i ett tema om segregation inom projektet Nordisk samverkan om integration. Projektet syftar till att underlätta samarbete mellan de nordiska länderna när det gäller integration av flyktingar och immigranter.

Läs mer på www.integrationnorden.org 